OPEN ACCESS

Edited by:

Carolina Elena Girometta,

University of Pavia, Italy

Reviewed by:

Yonghong Liu,

Chinese Academy of Sciences (CAS),

China

Pramod B. Shinde, Central Salt \& Marine Chemicals Research Institute (CSIR), India

*Correspondence:

C. Benjamin Naman bnaman@nbu.edu.cn

bnaman@ucsd.edu

Shan $\mathrm{He}$

heshan@nbu.edu.cn

Specialty section:

This article was submitted to

Microbiotechnology,

a section of the journal

Frontiers in Microbiology

Received: 07 December 2020

Accepted: 29 January 2021

Published: 22 February 2021

Citation:

Wang T, Zhou J, Zou J, Shi Y,

Zhou W, Shao P, Yu T, Cui W, Li X,

Wu X, Ye J, Yan X, Naman CB,

Lazaro JEH and He S (2021)

Discovery of Cymopolyphenols A-F

From a Marine Mesophotic Zone

Aaptos Sponge-Associated Fungus

Cymostachys sp. NBUF082.

Front. Microbiol. 12:638610.

doi: 10.3389/fmicb.2021.638610

\section{Discovery of Cymopolyphenols A-F From a Marine Mesophotic Zone Aaptos Sponge-Associated Fungus Cymostachys sp. NBUF082}

\author{
Tingting Wang ${ }^{1}$, Jing Zhou', Jiabin Zou', Yutong Shi', Wenli Zhou' ${ }^{2}$, Peng Shao', \\ Tianze $\mathrm{Yu}^{3}$, Wei Cui ${ }^{3}$, Xiaohui Li ${ }^{1}$, Xingxin $\mathrm{Wu}^{4}$, Jing Ye ${ }^{4}$, Xiaojun Yan', \\ C. Benjamin Naman ${ }^{1 *}$, J. Enrico H. Lazaro ${ }^{5}$ and Shan He ${ }^{1 *}$
}

1 Li Dak Sum Marine Biopharmaceutical Research Center, Department of Marine Pharmacy, College of Food and Pharmaceutical Sciences, Ningbo University, Ningbo, China, ${ }^{2}$ College of Fisheries, Tianjin Agricultural University, Tianjin, China, ${ }^{3}$ Zhejiang Provincial Key Laboratory of Pathophysiology, School of Medicine, Ningbo University, Ningbo, China, ${ }^{4}$ State Key Laboratory of Pharmaceutical Biotechnology, School of Life Sciences, Nanjing University, Nanjing, China, ${ }^{5}$ National Institute of Molecular Biology and Biotechnology, University of the Philippines Diliman, Quezon, Philippines

Mesophotic coral ecosystems (MCEs) have complex but understudied biodiversity, especially for natural products discovery. Untargeted metabolomics research on 80 extracts prepared from marine sponge-associated fungi, half from shallow reefs $(<30 \mathrm{~m})$ and half from MCEs (30-150 m), facilitated prioritization for further study a Cymostachys fungus from a $103 \mathrm{~m}$ deep Aaptos sponge. LC-MS target-directed isolation yielded a series of new compounds, cymopolyphenols A-F (1-6), and two known phenylspirodrimanes, F1839-I (7) and stachybotrylactone (8). This is the first report of natural products from the recently described genus, Cymostachys. Compounds 1-6 and $\mathbf{8}$ contain a dihydroisobenzofuran moiety, and 4-6 are low-order polymers of $\mathbf{1}$ with novel scaffolds. The structures of the compounds were established by spectroscopic and spectrometric data interpretation, with further support from X-ray crystallography studies of $\mathbf{3}$ and $\mathbf{4}$. Compound $\mathbf{3}$ undergoes facile racemization in solution and was found to crystalize as a racemic mixture. Compound $\mathbf{5}$ was also obtained in racemic form, and after chiral chromatography, both separated enantiomers racemized in solution by a presumed keto-enol tautomerization. Compounds $\mathbf{1}$ and 3-6 were found to be weakly antimicrobial (MIC 16-64 $\mu \mathrm{g} / \mathrm{ml}$ ) in vitro against several Gram-positive and Gram-negative human or aquatic pathogens, compound $\mathbf{5}$ was shown to chelate iron in vitro at $10 \mu \mathrm{M}$, and $\mathbf{8}$ activated plant disease resistance in vivo in a transgenic model organism.

Keywords: mesophotic coral ecosystems, twilight zone, sponges, fungi, sponge-associated fungi, natural products, polyphenols, dihydroisobenzofuran 


\section{INTRODUCTION}

Natural products research has long been instrumental in generating lead molecules for drug discovery, and many natural products have reached the clinic without structural modification by medicinal chemistry (Cragg et al., 2009; Lachance et al., 2012; Agarwal et al., 2020; Newman and Cragg, 2020). For decades, scientists have followed the adage that studying biodiversity leads to chemodiversity, and the continued exploration of environmental niches and different branches of life has been fruitful (Suffness and Douros, 1981). Studies of marine organisms were at one point considered to be pioneering, and now thousands of marine natural products have been reported. These have provided a resource for drug development and, "as shown at the global marine pharmaceutical pipeline website, ${ }^{1}$ there are currently nine approved marinederived pharmaceuticals, and an additional 31 compounds are either in Phase I, II, and III of clinical pharmaceutical development" (Mayer et al., 2020).

In the ocean, mesophotic coral ecosystems (MCEs, also known as twilight zone reefs) that range from 30 to $150 \mathrm{~m}$ deep represent an understudied environmental frontier for the collection of sponges and other macroscopic organisms that harbor diverse microbes (Olson and Kellogg, 2010; Weiss, 2017). It was reported that MCEs represent approximately $80 \%$ of coral reef habitat worldwide, yet very little is known about these deep habitats comparing to shallow reefs (Pyle and Copus, 2019). The biodiversity found in MCEs appears to differ significantly from that of shallow reefs, but a small fraction of life present there has been categorized taxonomically or examined in natural products research due to technical challenges (Sinniger et al., 2016; Lesser et al., 2018; Rocha et al., 2018). One strategy to access this resource is the investigation of assemblages produced from dredging, but this practice is extremely damaging to the environment (Machida et al., 2014; Pedrosa et al., 2020). Because most everything comes up broken into pieces, it is also challenging to determine the producing organism of any molecules discovered, e.g., by analytical comparison with extracts of sorted and identified biomass fragments (Machida et al., 2014; Pedrosa et al., 2020). More natural product studies have thus been reported on mesophotic zone organisms after being collected by a remotely operated vehicle (ROV) or autonomous underwater vehicle (AUV). However, this practice is very costly and usually reserved for studying the much deeper bathypelagic and abyssopelagic zones, or even hadopelagic trenches (Schupp et al., 2009). Scientific SCUBA diving to the mesophotic zone is preferable, but carries many challenges including the need for mixed gases, multiple tanks, and/or rebreather apparatus, and relatively few divers are trained for such depths. There are additionally dramatic safety limitations, including short working time at depth, long decompression stops to return to the surface, and risks of nitrogen narcosis and oxygen toxicity. Still, technical scientific diving is more eco-friendly than dredging and more cost-effective and efficient than using an ROV or AUV for sample collection.

${ }^{1}$ https://www.midwestern.edu/departments/marinepharmacology.xml
A previous preliminary survey of mesophotic zone organisms from Guam reported that "extracts from the twilight zone sponges and gorgonians resulted in an astonishing $72 \%$ hit rate" using in vitro cancer chemopreventive and antiproliferative bioassays and already yielded some new natural products (Schupp et al., 2009; Wright et al., 2012). While many researchers have studied macroscopic marine organisms, some natural products they discovered have been suspected or shown to be produced by associated microorganisms (Hirata and Uemura, 1986; Still et al., 2014; McCauley et al., 2020; Newman and Cragg, 2020). Recently, the multinational EU-funded program, TASCMAR (Tools And Strategies to access original bioactive compounds by Cultivating MARine invertebrates and associated symbionts $^{2}$ ), has begun to harness of the microbial diversity of some mesophotic zone invertebrates for the purpose of natural products discovery projects, and these have reported new bioactive molecules from interesting microbes (Le Goff et al., 2019; Nikolaivits et al., 2019; Letsiou et al., 2020).

Fungal metabolism is well-characterized as being diverse, and often leads to natural products with useful pharmacological activities, but may require efforts to activate in laboratory cultures as exemplified by the "One Strain, MAny Compounds" (OSMAC) approach (Keller, 2019). It is now typical to cultivate in a laboratory the microbes found associated with sponges, especially fungi, and then reproducibly access the biosynthetic potential of these organisms under different conditions ( $\mathrm{Li}$ and Wang, 2009; Zhang et al., 2020). Meanwhile, it is understood that mesophotic zone organisms represent a vastly unexplored biological diversity with great potential for natural products drug discovery. In the current study, sample prioritization was achieved by the OSMAC strategy combined with LC-MS/MS molecular networking (Wang et al., 2016) of organic extracts produced from 40 cultured fungi isolated from mesophotic zone sponges and 40 more from shallow reef sponges collected by scientific diving. This allowed a Cymostachys fungus to be selected for further study based on the observed production of then-hypothesized and now-demonstrated new natural products of interest.

The genus Cymostachys was only recently described, and no earlier literature exists on the natural products chemistry of any species therein (Lombard et al., 2016). Cymostachys is closely related to the genus Stachybotrys, and the latter has been extensively studied for its natural product chemistry (Wang et al., 2015; Zhao et al., 2017; Jagels et al., 2019; Zheng et al., 2019). For example, compounds 7 and $\mathbf{8}$ (Figure 1) were both originally discovered from Stachybotrys fungi (Ayer and Miao, 1993; Sakai et al., 1995; Zhao et al., 2017). The organism prioritization, targeted compound isolation and characterization of new molecules for ongoing natural product drug discovery efforts are described herein.

\section{MATERIALS AND METHODS}

\section{General Experimental Procedures}

Optical rotations were acquired on a JASCO P-2000 automatic polarimeter in $\mathrm{MeOH}$ at $20^{\circ} \mathrm{C}$. NMR spectra were recorded

${ }^{2}$ http://www.tascmar.eu/ 


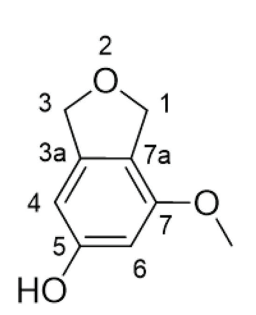

1

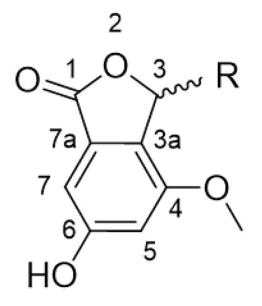

2: $\mathrm{R}=\mathrm{H}$

3: $\mathrm{R}=\mathrm{OH}$

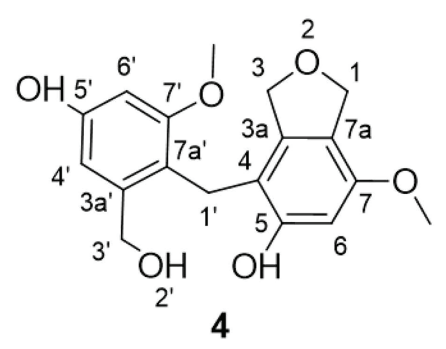

4

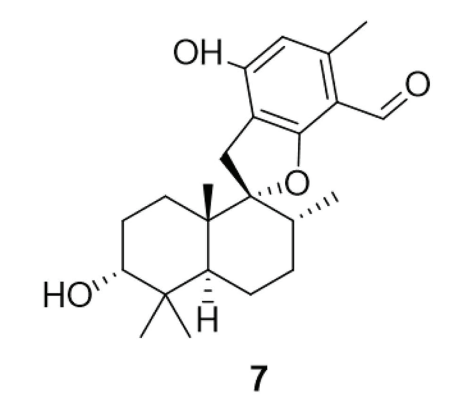

7<smiles>COc1cc(O)c([C@H]2OCc3cc(O)cc(OC)c32)c2c1COC2</smiles>

5

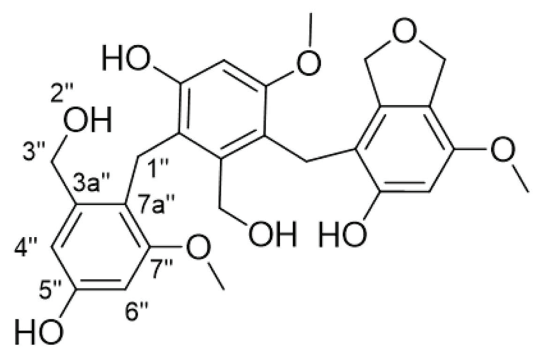

6

FIGURE 1 | Structures of compounds 1-8, here discovered from Cymostachys sp. NBUF082. Compounds $\mathbf{7}$ and $\mathbf{8}$ were previously reported from Stachybotrys fungi.

on a Bruker AVANCE NEO 600 spectrometer with a $5 \mathrm{~mm}$ inverse detection triple resonance (H-C/N/D) cryoprobe having z-gradients, and Bruker AVANCE 500 spectrometer with a $5 \mathrm{~mm}$ double resonance broadband room temperature probe. Spectra were collected using standard Bruker pulse programs, and chemical shifts were recorded relative to the solvent peak in DMSO- $d_{6}\left(\delta_{\mathrm{H}} 2.50\right.$ and $\left.\delta_{\mathrm{C}} 39.52\right)$. High-resolution electrospray ionization mass spectra (HRESIMS) were measured on an Agilent (Santa Clara, CA, United States) 6545 Q-TOF instrument. Reversed-phase HPLC purification was performed using a Waters HPLC equipped with a 1525 binary pump, and a Thermo Scientific (Waltham, MA, United States) ODS-2 Hypersil column $(5 \mu \mathrm{m}, 250 \mathrm{~mm} \times 10 \mathrm{~mm})$. Analytical chiral HPLC was performed using a Waters HPLC equipped with a 1525 binary pump and a Sepax Technologies (Newark, Delaware, United States) Chiralomix SA column $(5 \mu \mathrm{m}, 250 \mathrm{~mm} \times 4.6 \mathrm{~mm})$. Normal phase column chromatography and thin-layer chromatography were accomplished using coarse (200-300 mesh) and fine GF254 $(10-20 \mu \mathrm{m})$ silica, respectively (Qingdao Marine Chemical Company, China). Sephadex LH-20 (Pharmacia Biotech, Sweden) was used for gel filtration chromatography, and YMC*GEL ODS-A (AA12S50; YMC Co., Ltd., Japan) was used for reverse phase column chromatography. Biological assays were read for absorbance determination on a Thermo Scientific Multiskan GO microplate spectrophotometer.

\section{Organism Collection and Identification}

The fungi evaluated in this study were isolated from sponges collected in a shallow water reef and the deeper MCEs near
Apo Island, Negros Oriental, Philippines (904'40.6"N $123^{\circ} 15^{\prime} 57.3^{\prime \prime} \mathrm{E}$ and $\left.9^{\circ} 04^{\prime} 33.0^{\prime \prime} \mathrm{N} 123^{\circ} 15^{\prime} 59.1^{\prime \prime E}\right)$ by scientific technical SCUBA diving in October 2018. The details of specific sponge identification and sampling depths are listed in Supplementary Table S1. The fresh inner tissue of the each sponge was sliced and stuck on petri dishes containing modified Czapek's medium (sucrose $3.0 \mathrm{~g}, \mathrm{Na}_{2} \mathrm{NO}_{3} 3.0 \mathrm{~g}, \mathrm{MgSO}_{4} \cdot 7 \mathrm{H}_{2} \mathrm{O}$ $0.5 \mathrm{~g}, \mathrm{FeSO}_{4} \cdot 7 \mathrm{H}_{2} \mathrm{O} 0.001 \mathrm{~g}, \mathrm{KH}_{2} \mathrm{PO}_{4} 1.0 \mathrm{~g}$, $\mathrm{KCl} 0.5$ g, yeast extract $1.0 \mathrm{~g}$, kanamycin $150 \mathrm{mg}$, ampicillin sodium $150 \mathrm{mg}$, sea salt $35.0 \mathrm{~g}$, agar powder $20.0 \mathrm{~g}$, and $\mathrm{H}_{2} \mathrm{O}$ up to a total volume of $1 \mathrm{~L}$ ), modified potato dextrose agar (modified PDA: potato $20.0 \mathrm{~g}$, glucose $2.0 \mathrm{~g}$, kanamycin $150 \mathrm{mg}$, ampicillin sodium $150 \mathrm{mg}$, sea salt $35.0 \mathrm{~g}$, agar powder $20.0 \mathrm{~g}$, and $\mathrm{H}_{2} \mathrm{O}$ up to a total volume of $1 \mathrm{~L}$ ), and modified martin medium (peptone $10.0 \mathrm{~g}$, yeast extract $20.0 \mathrm{~g}$, sucrose $1.0 \mathrm{~g}, \mathrm{KH}_{2} \mathrm{PO}_{4}$ $1.0 \mathrm{~g}, \mathrm{MgSO}_{4} 0.5 \mathrm{~g}$, kanamycin $150 \mathrm{mg}$, ampicillin sodium $150 \mathrm{mg}$, sea salt $35.0 \mathrm{~g}$, agar powder $20.0 \mathrm{~g}$, and $\mathrm{H}_{2} \mathrm{O}$ up to a total volume of $1 \mathrm{~L}$ ). Two weeks later, fungal colonies on the plates were picked and purified on petri dishes containing PDA (glucose $20.0 \mathrm{~g}$, potato $200 \mathrm{~g}$, sea salt $35.0 \mathrm{~g}$, agar powder $20.0 \mathrm{~g}$, and $\mathrm{H}_{2} \mathrm{O}$ up to a total volume of $1 \mathrm{~L}$ ). Voucher specimens were deposited at the College of Food and Pharmaceutical Sciences, Ningbo University, Ningbo, China, available from $\mathrm{SH}$.

The fungal strain studied most extensively in this work, NBUF082, was inoculated at three points on PDA and cultivated at $28^{\circ} \mathrm{C}$ for 5 days. The fungal colonies were fast-growing and flocculated, and they turned from white to light brown color on cultivation day 5 . The reverse side of the medium was fawn-colored and non-extravasated. The strain was able to 
be identified as belonging to the genus Cymostachys according to its morphological traits (Lin et al., 2016), and sequence analysis of the ITS region (GenBank accession no. MW077215) as described previously (Henríquez et al., 2014; Lombard et al., 2016). Two other fungi were isolated from the same Aaptos sponge in addition to Cymostachys sp. NBUF082. These were identified as belonging to genera Roussoella and Aspergillus, respectively, based on morphological traits and sequence analysis of the ITS region (Henríquez et al., 2014).

\section{Small-Scale Cultivation, Extraction, and Molecular Networking}

Inspired by the OSMAC strategy, the obtained sponge-derived fungi were each cultured separately in three different types of media, potato dextrose broth (PDB: glucose $20.0 \mathrm{~g}$, potato $200.0 \mathrm{~g}$, sea salt $35.0 \mathrm{~g}$, and $\mathrm{H}_{2} \mathrm{O}$ up to a total volume of $1 \mathrm{~L}$ ), Czapek-Dox medium (sucrose $30.0 \mathrm{~g}, \mathrm{Na}_{2} \mathrm{NO}_{3} 3.0 \mathrm{~g}$, $\mathrm{MgSO}_{4} \cdot 7 \mathrm{H}_{2} \mathrm{O} 0.5 \mathrm{~g}, \mathrm{FeSO}_{4} \cdot 7 \mathrm{H}_{2} \mathrm{O} 0.001 \mathrm{~g}, \mathrm{KH}_{2} \mathrm{PO}_{4} 1.0 \mathrm{~g}, \mathrm{KCl}$ $0.5 \mathrm{~g}$, yeast extract $1.0 \mathrm{~g}$, sea salt $35.0 \mathrm{~g}$, and $\mathrm{H}_{2} \mathrm{O}$ up to a total volume of $1 \mathrm{~L}$ ), and modified Martin medium (peptone $10.0 \mathrm{~g}$, yeast extract $20.0 \mathrm{~g}$, sucrose $10.0 \mathrm{~g}, \mathrm{KH}_{2} \mathrm{PO}_{4} 1.0 \mathrm{~g}$, $\mathrm{MgSO}_{4} 0.5 \mathrm{~g}$, sea salt $35.0 \mathrm{~g}$, and $\mathrm{H}_{2} \mathrm{O}$ up to a total volume of $1 \mathrm{~L}$ ). The fungal mycelia on petri-dishes were cut into squares $\left(0.5 \mathrm{~cm}^{3} \times 0.5 \mathrm{~cm}^{3} \times 0.5 \mathrm{~cm}^{3}\right)$ and incubated into $1 \mathrm{~L}$ Erlenmeyer flasks containing $400 \mathrm{ml}$ of above-mentioned medium. The cultures were incubated for 15 days at $28^{\circ} \mathrm{C}$ with agitation $(120 \mathrm{rpm})$, and then extracted with $\mathrm{EtOAc}(\mathrm{v} / \mathrm{v}$, 1:1) three times each. The crude extracts were concentrated under vacuum with rotary evaporators.

The extracts were dissolved in $\mathrm{MeOH}$ to final concentrations of $1 \mathrm{mg} / \mathrm{ml}$ and preprocessed by $0.22 \mu \mathrm{m}$ membrane filtration. A $3 \mu \mathrm{l}$ aliquot of each sample was injected into the LC-HRESIMS and eluted at $0.8 \mathrm{ml} / \mathrm{min}\left(\mathrm{MeOH} / \mathrm{H}_{2} \mathrm{O}\right.$ with $0.1 \%$ formic acid, $\mathrm{v} / \mathrm{v}, 30 \% \rightarrow 99 \%$ ): $30 \%$ for $5 \mathrm{~min}$ to $99 \%$ in $17 \mathrm{~min}$, held for $3 \mathrm{~min}$, to $30 \%$ in $1 \mathrm{~min}$, and held for $4 \mathrm{~min}$. The mass spectrometer was set to observe $\mathrm{m} / \mathrm{z} 190-2000$ in positive ESI mode and with an automated data-dependent MS/MS scan enabled. The resulting data were uploaded to the Global Natural Product Social Molecular Networking web interface $\left(\mathrm{GNPS}^{3}\right)$, and the results were used to generate molecular network diagrams using the freely available open source visualization software, Cytoscape. ${ }^{4}$

\section{Large-Scale Fermentation, Extraction, and Isolation}

The Cymostachys fungus of interest was scaled up in culture size for chemical investigation. First, it was cultivated on potato dextrose agar (PDA) at $28^{\circ} \mathrm{C}$ for 7 days. The mycelia on PDA in petri dishes were cut into squares $\left(0.5 \mathrm{~cm}^{3} \times 0.5 \mathrm{~cm}^{3} \times 0.5 \mathrm{~cm}^{3}\right)$ and incubated into $280 \mathrm{~L} \times 1 \mathrm{~L}$ Erlenmeyer flasks, each containing $400 \mathrm{ml} \mathrm{PDB}$ medium ( $80 \mathrm{~g}$ potato dextrose, $8 \mathrm{~g}$ glucose, $14.0 \mathrm{~g}$ sea salt, and $400 \mathrm{ml} \mathrm{H}_{2} \mathrm{O}$ ). The cultures were incubated for 15 days at $28^{\circ} \mathrm{C}$ with agitation $(120 \mathrm{rpm})$ and then extracted with EtOAc (v/v, 1:1) for three times.

${ }^{3}$ http://gnps.ucsd.edu/

${ }^{4}$ https://cytoscape.org/
The combined organic phase was concentrated under reduced pressure to give $350 \mathrm{~g}$ (partially wet weight) of crude extract, which was subjected to column chromatography (CC) over silica gel (PE/EtOAc, v/v, 100:0 $\rightarrow 0: 100$ then EtOAc/MeOH v/v, 100:0 $\rightarrow 0: 100)$ to give 10 fractions (Fr.1-Fr.10). Of these, Fr.5, which eluted from the column with 1:1 PE/EtOAc, v/v, was separated with Sephadex LH-20 in MeOH to yield 15 subfractions (Fr.5.1-Fr.5.15). Fr.5.13 was further purified by RP-HPLC with $\mathrm{CH}_{3} \mathrm{CN} / \mathrm{H}_{2} \mathrm{O} \quad(45: 55,2 \mathrm{ml} / \mathrm{min})$ to afford compounds 4 $\left(t_{\mathrm{R}}=48 \mathrm{~min}, 11.3 \mathrm{mg}\right), 5\left(t_{\mathrm{R}}=42 \mathrm{~min}, 12.2 \mathrm{mg}\right)$, and $\mathbf{6}$ $\left(t_{\mathrm{R}}=57 \mathrm{~min}, 5.7 \mathrm{mg}\right)$. Crude Fr.6, which eluted from the column with EtOAc, was chromatographed again with silica gel (PE/EtOAc, v/v, 100:0 $\rightarrow 0: 100$ then EtOAc/MeOH v/v, 100:0 $\rightarrow 0: 100)$ to afford 10 subfractions (Fr.6.1-Fr.6.10). Fr.6.6 and Fr.6.7, which both eluted with EtOAc, were subjected to RP-HPLC to yield compounds $7\left(t_{\mathrm{R}}=30 \mathrm{~min}, 3.4 \mathrm{mg}\right)$ and $8\left(t_{\mathrm{R}}=39 \mathrm{~min}, 14.6 \mathrm{mg}\right)$ by elution with $\mathrm{CH}_{3} \mathrm{CN} / \mathrm{H}_{2} \mathrm{O}(42: 58$, $2 \mathrm{ml} / \mathrm{min})$ and $\mathrm{CH}_{3} \mathrm{CN} / \mathrm{H}_{2} \mathrm{O}(45: 55,2 \mathrm{ml} / \mathrm{min})$, respectively. Fr. 6.8, which was eluted from the column by $40: 1$ EtOAc/ $\mathrm{MeOH}, \mathrm{v} / \mathrm{v}$, was separated with Sephadex LH-20 in $\mathrm{MeOH}$ to yield 15 subfractions (Fr.6.8.1-Fr.6.8.15). Further purification of Fr.6.8.8 via RP-HPLC $\left(\mathrm{CH}_{3} \mathrm{CN} / \mathrm{H}_{2} \mathrm{O}, 36: 64,2 \mathrm{ml} / \mathrm{min}\right)$ afforded compounds $1\left(t_{\mathrm{R}}=28 \mathrm{~min}, 10.2 \mathrm{mg}\right)$ and $2\left(t_{\mathrm{R}}=30 \mathrm{~min}\right.$, $0.8 \mathrm{mg}$ ). Fr. 6.9, which was eluted from the column by $20: 1$ EtOAc/MeOH, v/v, was separated with Sephadex LH-20 in $\mathrm{MeOH}$ to yield fifteen subfractions (Fr.6.9.1-Fr.6.9.15). Subfraction Fr.6.9.5 yielded $3\left(t_{\mathrm{R}}=25 \mathrm{~min}, 10.0 \mathrm{mg}\right)$ after being subjected to RP-HPLC $\left(\mathrm{CH}_{3} \mathrm{CN} / \mathrm{H}_{2} \mathrm{O}, 50: 50,2 \mathrm{ml} / \mathrm{min}\right)$.

\section{Isolated Materials (New Natural Products)}

Cymopolyphenol A (1): White powder; UV (MeOH) $\lambda_{\max }$ $(\log \varepsilon)=280(3.74) \mathrm{nm}$; for ${ }^{1} \mathrm{H}$ NMR and ${ }^{13} \mathrm{C}$ NMR data

TABLE 1 $\mid{ }^{1} \mathrm{H}$ and ${ }^{13} \mathrm{C}$ NMR spectroscopic data for 1-3 in DMSO- $d_{6}{ }^{a}$.

\begin{tabular}{|c|c|c|c|c|c|c|}
\hline \multirow[t]{2}{*}{ Position } & \multicolumn{2}{|c|}{1} & \multicolumn{2}{|c|}{2} & \multicolumn{2}{|c|}{3} \\
\hline & $\delta_{\mathrm{c}}$, type & $\begin{array}{c}\delta_{H}(J \text { in } \\
H z)\end{array}$ & $\delta_{\mathrm{c}}$, type & $\begin{array}{c}\delta_{\mathrm{H}}(J \text { in } \\
\mathrm{Hz})\end{array}$ & $\delta_{\mathrm{c}}$, type & $\begin{array}{c}\delta_{H}(J \text { in } \\
H z)\end{array}$ \\
\hline 1 & $70.9, \mathrm{CH}_{2}$ & $4.84 \mathrm{t}(2.3)$ & $170.8, \mathrm{C}$ & & 168.1, C & \\
\hline 3 & 73.1, $\mathrm{CH}_{2}$ & $\begin{array}{c}4.88 \mathrm{t} \\
(2.3)\end{array}$ & $\begin{array}{l}\text { 68.0 } \\
\mathrm{CH}_{2}\end{array}$ & $5.23 \mathrm{~s}$ & $\begin{array}{c}\text { 102.0 } \\
\mathrm{CH}\end{array}$ & $6.44 \mathrm{~s}$ \\
\hline $3 a$ & 141.5, C & & 125.9, C & & 122.5, C & \\
\hline 4 & $99.7, \mathrm{CH}$ & $6.26 \mathrm{~s}^{b}$ & 154.9, C & & 156.1, C & \\
\hline 5 & 159.1, C & & $\begin{array}{c}\text { 105.0 } \\
\mathrm{CH}\end{array}$ & $\begin{array}{c}6.75 \mathrm{~d} \\
(1.8)\end{array}$ & $\begin{array}{c}105.2 \\
\mathrm{CH}\end{array}$ & $\begin{array}{c}6.75 \mathrm{~d} \\
(1.8)\end{array}$ \\
\hline 6 & $97.7, \mathrm{CH}$ & $6.27 \mathrm{~s}^{b}$ & 160.3, C & & 161.8, C & \\
\hline 7 & 154.3, C & & $\begin{array}{c}101.4 \\
\mathrm{CH}\end{array}$ & $\begin{array}{l}6.71 \mathrm{~d} \\
(1.8)\end{array}$ & $\begin{array}{c}101.6 \\
\mathrm{CH}\end{array}$ & $\begin{array}{c}6.70 \mathrm{~d} \\
(1.8)\end{array}$ \\
\hline $7 a$ & 116.3, C & & $127.2, \mathrm{C}$ & & 129.2, C & \\
\hline $7-\mathrm{OCH}_{3}$ & $55.0, \mathrm{CH}_{3}$ & $3.71 \mathrm{~s}$ & & & & \\
\hline $4-\mathrm{OCH}_{3}$ & & & $\begin{array}{l}55.8 \\
\mathrm{CH}_{3}\end{array}$ & $3.83 \mathrm{~s}$ & $\begin{array}{c}55.8 \\
\mathrm{CH}_{3}\end{array}$ & $3.83 \mathrm{~s}$ \\
\hline $5-\mathrm{OH}$ & & 9.46 br s & & & & \\
\hline $6-\mathrm{OH}$ & & & & $10.21 \mathrm{br} \mathrm{s}$ & & $10.39 \mathrm{~s}$ \\
\hline
\end{tabular}

${ }^{a}$ Data recorded at $298 \mathrm{~K}, 600 \mathrm{MHz}\left({ }^{1} \mathrm{H}\right)$ and $150 \mathrm{MHz}\left({ }^{13} \mathrm{C}\right)$. Assignments supported by 2D NMR.

${ }^{b}$ Partially overlapped. 
see Table 1; HR-ESI-MS $[\mathrm{M}+\mathrm{H}]^{+} \mathrm{m} / z 167.0706$ (calcd. for $\mathrm{C}_{9} \mathrm{H}_{11} \mathrm{O}_{3}, 167.0703$ ).

Cymopolyphenol B (2): White powder; UV (MeOH) $\lambda_{\max }$ $(\log \varepsilon)=285(3.08) \mathrm{nm}$; for ${ }^{1} \mathrm{H}$ NMR and ${ }^{13} \mathrm{C}$ NMR data see Table 1; HR-ESI-MS $[\mathrm{M}+\mathrm{H}]^{+} \mathrm{m} / z 181.0500$ (calcd. for $\left.\mathrm{C}_{9} \mathrm{H}_{9} \mathrm{O}_{4}, 181.0495\right)$.

Cymopolyphenol C (3): Colorless prisms; $[\alpha]_{\mathrm{D}}^{25} 0$ (c 0.1 , $\mathrm{MeOH}) ; \mathrm{UV}(\mathrm{MeOH}) \lambda_{\max }(\log \varepsilon)=285$ (3.11) nm; for ${ }^{1} \mathrm{H}$

TABLE $2 \mid{ }^{1} \mathrm{H}$ and ${ }^{13} \mathrm{C}$ NMR Spectroscopic Data for 4-6 in DMSO- $d_{6}{ }^{a}$.

\begin{tabular}{|c|c|c|c|c|c|c|}
\hline \multirow[t]{2}{*}{ Position } & \multicolumn{2}{|c|}{4} & \multicolumn{2}{|c|}{5} & \multicolumn{2}{|c|}{6} \\
\hline & $\delta_{c}$, type & $\begin{array}{c}\delta_{\mathrm{H}}(\boldsymbol{J} \text { in } \\
\mathbf{H z})\end{array}$ & $\delta_{c}$, type & $\begin{array}{c}\boldsymbol{\delta}_{\mathrm{H}}(\boldsymbol{J} \text { in } \\
\mathrm{Hz})\end{array}$ & $\delta_{c}$, type & $\begin{array}{c}\delta_{H}(\boldsymbol{J} \text { in } \\
H z)\end{array}$ \\
\hline 1 & 70.3, $\mathrm{CH}_{2}$ & $\begin{array}{c}4.70 \mathrm{t} \\
(2.4)\end{array}$ & $\begin{array}{l}70.2 \\
\mathrm{CH}_{2}\end{array}$ & $4.72 \mathrm{~m}$ & $70.1, \mathrm{CH}_{2}$ & $\begin{array}{l}4.67 t \\
(2.3)\end{array}$ \\
\hline \multirow[t]{2}{*}{3} & 71.8, $\mathrm{CH}_{2}$ & $\begin{array}{c}4.16 \mathrm{t} \\
(2.4)\end{array}$ & $\begin{array}{l}71.6 \\
\mathrm{CH}_{2}\end{array}$ & $\begin{array}{l}4.49 \mathrm{br} \\
\mathrm{d}(12.7)\end{array}$ & 71.9, $\mathrm{CH}_{2}$ & $\begin{array}{c}4.00 t \\
(2.3)\end{array}$ \\
\hline & & & & $\begin{array}{l}3.99 \mathrm{br} \\
\mathrm{d}(12.7)\end{array}$ & & \\
\hline $3 a$ & 139.5, C & & 140.0, C & & 139.5, C & \\
\hline 4 & $112.8, \mathrm{C}$ & & 114.3, C & & 114.1, C & \\
\hline 5 & 155.6, C & & 156.2, C & & $155.4, \mathrm{C}$ & \\
\hline 6 & $97.7, \mathrm{CH}$ & $6.37 \mathrm{~s}$ & $97.8, \mathrm{CH}$ & $6.36 \mathrm{~s}$ & $97.6, \mathrm{CH}$ & $6.38 \mathrm{~s}$ \\
\hline 7 & $151.4, \mathrm{C}$ & & 153.0, C & & $151.2, \mathrm{C}$ & \\
\hline $7 a$ & 116.4, C & & 116.6, C & & 116.2, C & \\
\hline $5-\mathrm{OH}$ & & $9.43 \mathrm{~s}$ & & $9.45 \mathrm{~s}$ & & \\
\hline $7-\mathrm{OCH}_{3}$ & $54.9, \mathrm{CH}_{3}$ & $3.678 s^{b}$ & $\begin{array}{c}54.9 \\
\mathrm{CH}_{3}\end{array}$ & $3.71 \mathrm{~s}$ & $54.8, \mathrm{CH}_{3}$ & $3.68 \mathrm{~s}$ \\
\hline $1^{\prime}$ & 21.1, $\mathrm{CH}_{2}$ & $\begin{array}{c}3.674 \mathrm{br} \\
\mathrm{s}^{b}\end{array}$ & $76.4, \mathrm{CH}$ & $\begin{array}{c}6.41 \mathrm{dd} \\
(3.0,1.9)\end{array}$ & 22.6, $\mathrm{CH}_{2}$ & $3.84 \mathrm{~s}^{c}$ \\
\hline \multirow[t]{2}{*}{$3^{\prime}$} & 60.0, $\mathrm{CH}_{2}$ & $4.23 \mathrm{~s}$ & $\begin{array}{c}72.4 \\
\mathrm{CH}_{2}\end{array}$ & $\begin{array}{c}5.00 \mathrm{dd} \\
(12.4 \\
3.0)\end{array}$ & 57.1, $\mathrm{CH}_{2}$ & $4.39 \mathrm{~s}$ \\
\hline & & & & $\begin{array}{c}4.84 \mathrm{dd} \\
(12.4 \\
1.9)\end{array}$ & & \\
\hline 3a' & 143.3, C & & $142.4, \mathrm{C}$ & & $141.2, \mathrm{C}$ & \\
\hline $4^{\prime}$ & 105.3, $\mathrm{CH}$ & $\begin{array}{c}6.52 \mathrm{~d} \\
(2.4)\end{array}$ & $99.3, \mathrm{CH}$ & $\begin{array}{c}6.27 \mathrm{~d} \\
(1.8)\end{array}$ & 119.0, C & \\
\hline $5^{\prime}$ & 156.7, C & & 159.3, C & & $154.8, \mathrm{C}$ & \\
\hline $6^{\prime}$ & 96.9, $\mathrm{CH}$ & $\begin{array}{c}6.28 \mathrm{~d} \\
(2.4)\end{array}$ & $97.9, \mathrm{CH}$ & $\begin{array}{c}6.23 \mathrm{~d} \\
(1.8)\end{array}$ & 98.0, $\mathrm{CH}$ & $6.30 \mathrm{~s}$ \\
\hline $7^{\prime}$ & 158.2, C & & $154.9, \mathrm{C}$ & & 156.0, C & \\
\hline $7 a^{\prime}$ & 114.2, C & & 117.8, C & & 117.0, C & \\
\hline 5'-OH & & $9.23 \mathrm{~s}$ & & $9.49 \mathrm{~s}$ & & \\
\hline $7^{\prime}-\mathrm{OCH}_{3}$ & 55.3, $\mathrm{CH}_{3}$ & $3.682^{b} \mathrm{~s}$ & $\begin{array}{l}55.2 \\
\mathrm{CH}_{3}\end{array}$ & $3.52 \mathrm{~s}$ & $55.0, \mathrm{CH}_{3}$ & $3.61 \mathrm{~s}$ \\
\hline $1 "$ & & & & & 22.4, $\mathrm{CH}_{2}$ & $3.76 \mathrm{~s}^{c}$ \\
\hline 3" & & & & & $61.1, \mathrm{CH}_{2}$ & $4.54 \mathrm{~s}$ \\
\hline За" & & & & & $142.2, \mathrm{C}$ & \\
\hline 4" & & & & & $\begin{array}{c}\text { 105.9 } \\
\mathrm{CH}\end{array}$ & $\begin{array}{c}6.44 d \\
(2.4)\end{array}$ \\
\hline 5" & & & & & 155.8, C & \\
\hline 6" & & & & & $97.3, \mathrm{CH}$ & $\begin{array}{c}6.14 \mathrm{~d} \\
(2.4)\end{array}$ \\
\hline 7" & & & & & 158.2, C & \\
\hline 7a" & & & & & 117.3, C & \\
\hline $7^{\prime \prime}-\mathrm{OCH}_{3}$ & & & & & $54.5, \mathrm{CH}_{3}$ & $3.35 \mathrm{~s}$ \\
\hline
\end{tabular}

${ }^{a}$ Data recorded at $298 \mathrm{~K}, 600 \mathrm{MHz}\left({ }^{\prime} \mathrm{H}\right)$ and $150 \mathrm{MHz}\left({ }^{(13} \mathrm{C}\right)$ or $500 \mathrm{MHz}\left({ }^{\prime} H\right)$ and $125 \mathrm{MHz}\left({ }^{13} \mathrm{C}\right)$. Assignments supported by 2D NMR.

${ }^{b}$ Signals partially overlapped.

'Might be interchanged.
NMR and ${ }^{13} \mathrm{C}$ NMR data see Table 1; HR-ESI-MS $[\mathrm{M}+\mathrm{H}]^{+}$ $m / z 197.0453$ (calcd. for $\mathrm{C}_{9} \mathrm{H}_{9} \mathrm{O}_{5}, 197.0444$ ).

Cymopolyphenol D (4): Colorless prisms; UV (MeOH) $\lambda_{\max }$ $(\log \varepsilon)=290$ (3.66); for ${ }^{1} \mathrm{H}$ NMR and ${ }^{13} \mathrm{C}$ NMR data see Table 2; HR-ESI-MS $[\mathrm{M}+\mathrm{Na}]^{+} \mathrm{m} / z 355.1159$ (calcd. for $\left.\mathrm{C}_{18} \mathrm{H}_{20} \mathrm{O}_{6} \mathrm{Na}, 355.1152\right)$.

Cymopolyphenol E (5): Light brown powder; $[\alpha]_{\mathrm{D}}^{25} 0$ (c 0.1 , $\mathrm{MeOH}) ; \mathrm{UV}(\mathrm{MeOH}) \lambda_{\max }(\log \varepsilon)=285(3.82) \mathrm{nm}$; for ${ }^{1} \mathrm{H}$ NMR and ${ }^{13} \mathrm{C}$ NMR data see Table 2; HR-ESI-MS [M + $\mathrm{Na}]^{+} \mathrm{m} / z 353.0997$ (calcd. for $\mathrm{C}_{18} \mathrm{H}_{18} \mathrm{O}_{6} \mathrm{Na}, 353.0996$ ).

Cymopolyphenol $F$ (6): White powder; UV $(\mathrm{MeOH}) \lambda_{\max }$ $(\log \varepsilon)=285(3.81) \mathrm{nm}$; for ${ }^{1} \mathrm{H}$ NMR and ${ }^{13} \mathrm{C}$ NMR data see Table 2; HR-ESI-MS $[\mathrm{M}+\mathrm{Na}]^{+} \mathrm{m} / z 521.1790$ (calcd. for $\mathrm{C}_{27} \mathrm{H}_{30} \mathrm{O}_{9} \mathrm{Na}, 521.1782$ ).

\section{Single Crystal X-ray Diffraction Analysis}

The crystals obtained for $\mathbf{3}$ and $\mathbf{4}$ were evaluated on a Bruker APEX-II CCD diffractometer through Ga K $\alpha(\lambda=1.34139 \AA)$. The structures were solved by direct methods (SHELXT-2014) and refined via full-matrix least-squares difference Fourier techniques using SHELXL-2018/3. Crystallographic data for the structures reported in this paper have been deposited with the Cambridge Crystallographic Data Centre. Copies of the data can be obtained, free of charge, on application to the Director, CCDC, 12 Union Road, Cambridge CB2 1EZ, United Kingdom (fax: +44-(0)1223-336033 or e-mail: deposit@ccdc.cam.ac.uk).

Crystallographic data for 3: $\mathrm{C}_{9} \mathrm{H}_{8} \mathrm{O}_{5}, M_{\mathrm{r}}=196.15$, prism from $\mathrm{MeOH} / \mathrm{H}_{2} \mathrm{O}$ (50:1), space group $C \mathrm{c}, a=3.8907(3) \AA$, $b=15.5114(11) \AA, c=13.8032(10) \AA, V=827.53(11) \AA^{3}$, $Z=4, \mu=0.718 \mathrm{~mm}^{-1}, F(000)=408.0$; crystal size: $0.120 \mathrm{~mm}^{3} \times 0.110 \mathrm{~mm}^{3} \times 0.090 \mathrm{~mm}^{3} ; 1,478$ unique reflections with 1,368 obeying the $I \geq 2 \sigma(I) ; R=0.0336(1368)$, $w R 2=0.0849(1478), S=1.055$; supplementary publication no. CCDC-2027079.

Crystallographic data for 4: $\mathrm{C}_{18} \mathrm{H}_{20} \mathrm{O}_{6}, M_{\mathrm{r}}=332.34$, prism from $\mathrm{MeOH} / \mathrm{DCM}$ (40:1), space group $P_{-1}, a=4.8536(2)$ $\AA, b=11.5267(5) \AA, c=14.9026(7) \AA, V=769.37(6) \AA^{3}$, $Z=2, \mu=0.572 \mathrm{~mm}^{-1}, F(000)=352.0$; crystal size: $0.120 \mathrm{~mm}^{3} \times 0.110 \mathrm{~mm}^{3} \times 0.080 \mathrm{~mm}^{3} ; 2,792$ unique reflections with 2,287 obeying the $I \geq 2 \sigma(I) ; R=0.0377(2287)$, $w R 2=0.1016(2792), S=1.030$; supplementary publication no. CCDC-2019163.

\section{In vitro Cytotoxicity Test Protocols}

Compounds $\mathbf{1}$ and 3-8 were tested in serial dilutions from the maximum concentration of $20 \mu \mathrm{M}$ for their inhibition toward CCRF-CEM human $\mathrm{T}$ lymphoblast cells via lactate dehydrogenase testing and U87 human glioblastoma with MTT according to published protocols (Boudreau et al., 2012; Williams et al., 2017).

\section{In vitro Antimicrobial Assay Protocols}

Antibacterial susceptibility was tested against several Grampositive and Gram-negative human or aquatic pathogens, namely Pseudoalteromonas carrageenovora, Vibrio shilanii, V. scophthalmi, 
V. alginolyticus, Salmonella typhi, Pseudomonas aeruginosa, Staphylococcus aureus, and Bacillus pumilus. Compounds $\mathbf{1}$ and 3-8 were dissolved in DMSO and tested at a concentration of $64,32,16,8$, and $4 \mu \mathrm{g} / \mathrm{ml}$ according to a published protocol (CLSI, 2018; Bibi et al., 2020). Briefly, the bacteria were grown in $\mathrm{MH}$ medium (beef powder $6.0 \mathrm{~g}$, soluble starch $1.5 \mathrm{~g}$, acid hydrolyzed casein $17.5 \mathrm{~g}$, and $\mathrm{H}_{2} \mathrm{O}$ up to a total volume of $1 \mathrm{~L}$ ) for $24 \mathrm{~h}$ at $28^{\circ} \mathrm{C}$ with agitation $(180 \mathrm{rpm})$, then diluted with sterile $\mathrm{MH}$ medium to match $0.5 \mathrm{McFarland}$ standard. $100 \mu \mathrm{l}$ of each bacteria supernatant, $100 \mu \mathrm{MH}$ medium with $0.001 \%$ 2,3,5-triphenyltetrazolium chloride (an indicator of viable bacteria), together with test or control materials were incubated in $96-$ well plates. The treated bacteria were cultured statically at $28^{\circ} \mathrm{C}$ for $24 \mathrm{~h}$, then the inhibition data were recorded optically. Norfloxacin (from Shanghai Yuanye Bio-Technology Co., Ltd.) was used as positive control, and this was dissolved in DMSO at the same concentrations as the tested compounds. Blank media with the same volume of DMSO as the test samples was used as the negative control.

\section{Iron Chelation Evaluation}

Ferrozine can chelate $\mathrm{Fe}^{2+}$ to afford a complex with an absorbance at $562 \mathrm{~nm}$, which allows for a facile chemical assay that was repeated according to published protocols (Da Lozzo et al., 2002; Azran et al., 2015). In brief, the reaction system on a 96-well plate was composed of $160 \mu \mathrm{l} \mathrm{CH}_{3} \mathrm{COONa}(100 \mathrm{mM}), 40 \mu \mathrm{l}$ $\mathrm{FeCl}_{2}(1.5 \mathrm{mg} / \mathrm{ml})$, and $10 \mu \mathrm{l}$ of compounds 1 and 3-8 (0.3, $1,3$, and $10 \mu \mathrm{M})$, separately. At the same concentrations, EDTA, a known chelator of $\mathrm{Fe}^{2+}$ was used as a positive control. The reaction medium, $\mathrm{CH}_{3} \mathrm{COONa}(100 \mathrm{mM})$, was used as a negative control. Following sample addition and 30-min light-proof standing, $10 \mu \mathrm{l}$ ferrozine $(40 \mathrm{mM})$ was added and the absorbance at $562 \mathrm{~nm}$ was collected after another 5-min light-proof standing.

\section{In vivo Activation of the GUS Reporter in PR1::GUS Transgenic Arabidopsis thaliana Plants}

Following a published method (Wang et al., 2018), clean Arabidopsis thaliana seeds ProPR1::GUS (purchased from Arabidopsis Biological Resource Center) were sown in Murashige and Skoog medium (PhytoTechnology Laboratories, United States), with or without added individual compounds $\mathbf{1}$ and $3-8$ at $10 \mu \mathrm{M}$ and maintained at $4^{\circ} \mathrm{C}$. After 3 days, the culture conditions were altered to $22^{\circ} \mathrm{C}$ with a $16 \mathrm{~h}$ light $/ 8 \mathrm{~h}$ dark photoperiod. After another 10 days, the plants were dyed in GUS histochemical staining stock at $37^{\circ} \mathrm{C}$ for $3 \mathrm{~h}$, and the chlorophyll of the plants were washed with $70 \%$ ethanol. Observation and photo documentation of the results were carried out with an optical microscope.

\section{RESULTS AND DISCUSSION}

\section{Sample Prioritization}

From a series of sponges that were collected at diverse depths of 7-103 m (Supplementary Table S1), some 80 fungal strains were isolated in laboratory culture by conventional methods (Höller et al., 2000; Liu et al., 2019). The fungal strains were divided into two groups of each $n=40$, representing shallow reef and MCE origins of the sponges that yielded the isolated microbial samples. Each strain $(n=80)$ was cultivated in smallscale replicates using three different types of growth media to evaluate their secondary metabolite production potential by the OSMAC approach. Organic extracts were prepared from all 240 strain-media combination cultures and evaluated by TLC. The most natural product-rich culture of each strain was selected for further evaluation by untargeted LC-MS/MS analysis $(n=80)$. All obtained data were analyzed together using the Global Natural Product Social Molecular Networking (GNPS) web interface (Wang et al., 2016). A molecular network was prepared and annotated (Figure 2), from which it was obvious that the extracts of fungal strains prepared from MCE sponge samples were largely distinct from their shallow water counterparts. Although this remains a relatively small sample set of $n=40$ per group, the major compositional difference between the MCE and shallow reef samples here analyzed is postulated to be a widespread phenomenon. Further sample collections and laboratory investigations are planned for evaluating this hypothesis.

One organism from the MCE subset of the above strain library was selected for further study in part because the morphology of the producing organism separated it from typically studied genera of fungal natural product producers. Upon close examination of the literature, it was determined that the morphology of strain NBUF082 matched what was described for the genus Cymostachys when it was established in recent reports, and it was also conclusively identified as a Cymostachys sp. by the ITS region sequence of this organism (Lin et al., 2016; Lombard et al., 2016). Although Cymostachys is closely related to the genus Stachybotrys, only the latter has been extensively studied for its natural product chemistry (Wang et al., 2015; Zhao et al., 2017; Jagels et al., 2019; Zheng et al., 2019). In contrast, no natural products reported from Cymostachys could be found at the onset of this study, and it was proposed that this organism could produce new and interesting natural products chemistry.

Furthermore, the result of using the OSMAC approach to screen the 240 strain $\mathrm{x}$ culture condition set of combinations showed that the Cymostachys sp. NBUF082 was a moderately high yielding producer of natural products when grown on potato dextrose agar (PDA). With this media, the organism generated $451.8 \mathrm{mg} / \mathrm{L}$ organic extract, compared with a range from about $5 \mathrm{mg} / \mathrm{L}$ to $1 \mathrm{~g} / \mathrm{L}$ for other strain $\mathrm{x}$ culture condition combinations. When the extract from this sample was evaluated by LC-MS/MS molecular networking, it was selected for further study based on the observation of several distinct molecules compared to the remainder of the data set. The nodes in the network owing to this sample have been colored green in Figure 2 to show how it stood out from all the 40 shallow reef and the remaining 39 MCE originating sponge-derived fungi. Many more broadly distributed metabolites and molecular feature node clusters were observed to be shared between data sets resulting from shallow and MCE samples, and these are apparent as split-color pie graph nodes in Figure 2. 


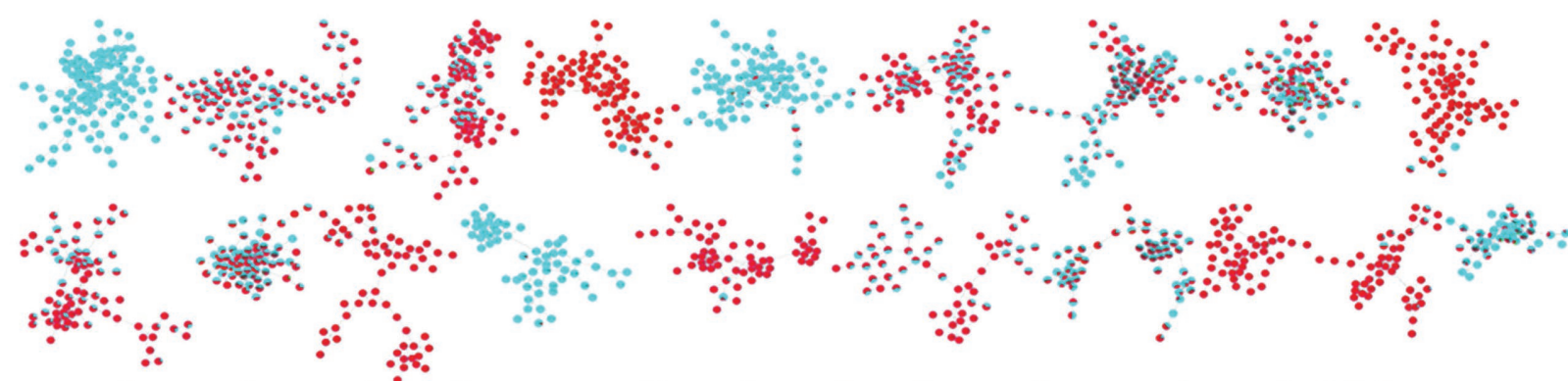

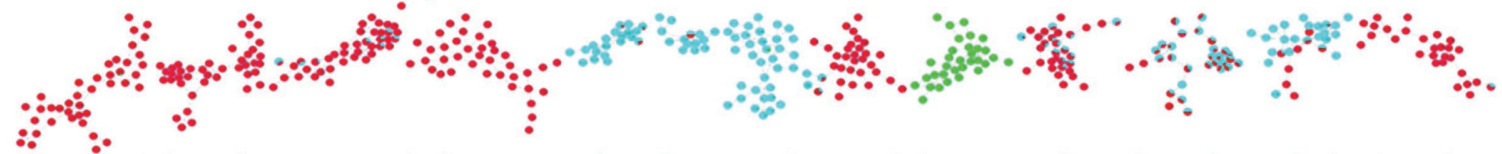
䑸 $\because 0^{\circ}$

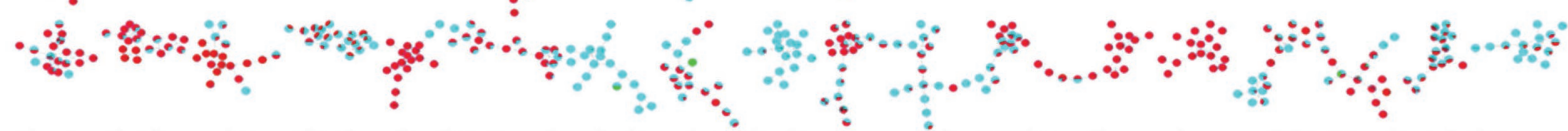

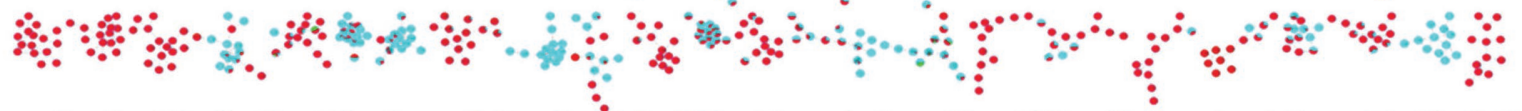
$\because$\begin{tabular}{c}
0 \\
\hdashline
\end{tabular} \begin{tabular}{c}
0 \\
\hdashline
\end{tabular}

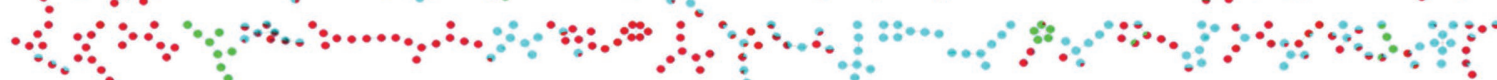

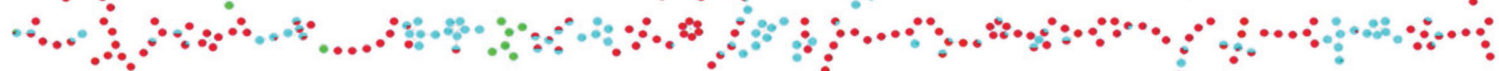

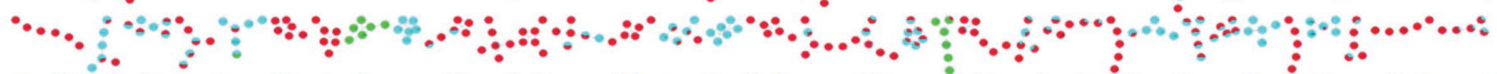

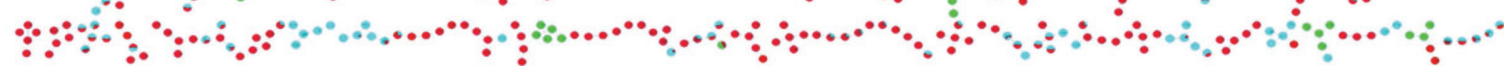

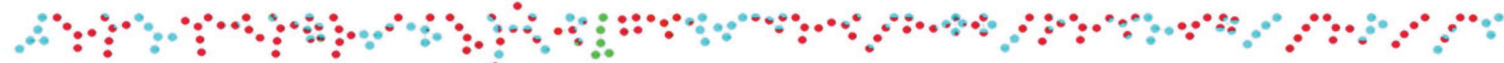

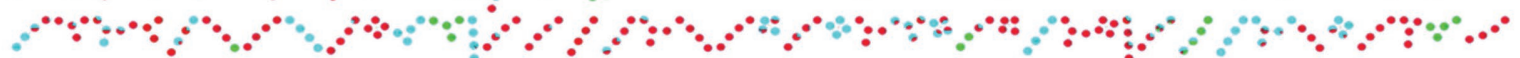

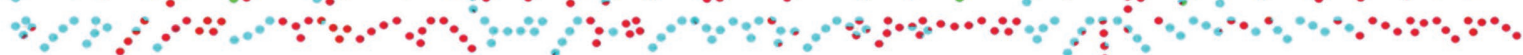
$\therefore$

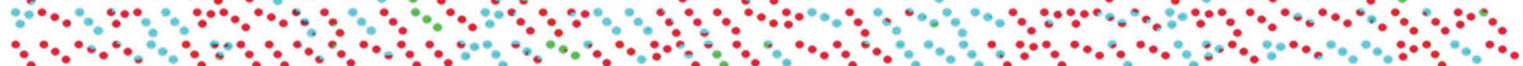
$\because \because \therefore-8 \div$

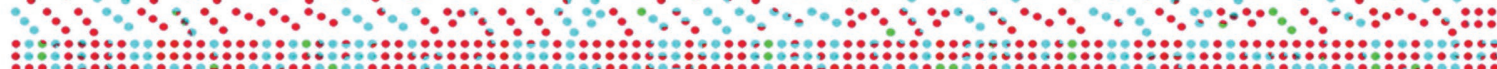

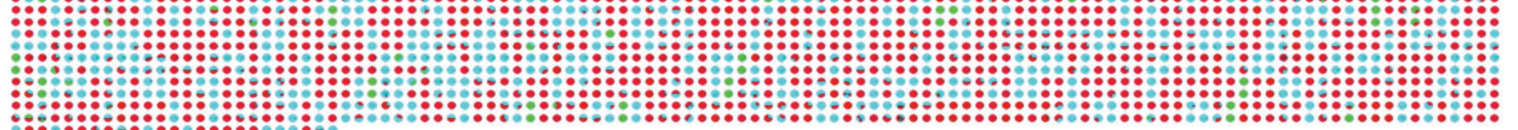
:

\section{LEGEND \\ Mesophotic reef Aaptos sponge- associated Cymostachys fungus


Some metabolites were found to be more broadly distributed, but exclusively observed in the same depth-based subsets, and these were purposefully overlooked for prioritization in this research study. For example, metabolites coming from two or more shallow-derived samples and not the MCE subset were lumped together (shown in only blue in Figure 2) and avoided for targeted isolation here, as were those resulting from two or more MCE-derived samples but not the shallow subset (shown in only red in Figure 2). The prioritized fungal strain, Cymostachys sp. NBUF082, was cultivated in large-scale for natural product discovery. Some other fungal samples along with their OSMAC culture conditions from the 240 combination set were also considered to be chemically interesting, and these were ranked lower in priority to be investigated and reported on in due time.

\section{Structure Elucidation}

Compound 1 was obtained as a white powder and assigned the molecular formula $\mathrm{C}_{9} \mathrm{H}_{10} \mathrm{O}_{3}$ based on a proton adduct peak in the HRESIMS spectrum at $m / z 167.0706[\mathrm{M}+\mathrm{H}]^{+}$(calcd. for $\mathrm{C}_{9} \mathrm{H}_{11} \mathrm{O}_{3}, 167.0703$ ). This formula indicated that $\mathbf{1}$ possessed five degrees of unsaturation. The ${ }^{1} \mathrm{H}$ and ${ }^{13} \mathrm{C}$ NMR data of $\mathbf{1}$ (Table 1) demonstrated the existence of one methoxy group $\left(\delta_{\mathrm{H}} 3.71, \delta_{\mathrm{C}} 55.0 ; 7-\mathrm{O}-\mathrm{CH}_{3}\right)$, two oxygenated methylenes $\left(\delta_{\mathrm{H}}\right.$ $4.84, \delta_{\mathrm{c}} 70.9 ; \mathrm{CH}_{2}-1$ and $\left.\delta_{\mathrm{H}} 4.88, \delta_{\mathrm{C}} 73.1 ; \mathrm{CH}_{2}-3\right)$, two aromatic methines $\left(\delta_{\mathrm{H}} 6.26, \delta_{\mathrm{C}} 99.7 ; \mathrm{CH}-4\right.$ and $\left.\delta_{\mathrm{H}} 6.27, \delta_{\mathrm{C}} 97.7 ; \mathrm{CH}-6\right)$, and four nonprotonated $\mathrm{sp}^{2}$ carbons $\left(\delta_{\mathrm{C}} 141.5\right.$; C-3a, $\delta_{\mathrm{C}} 159.1$; C-5, $\delta_{\mathrm{C}} 154.3$; C-7, and $\delta_{\mathrm{C}} 116.3$; C-7a). A substituted phenolic group was deduced from the 1D NMR data, which accounted for four of five required degrees of unsaturation. The downfield protons $\mathrm{CH}_{2}-1$ and $\mathrm{CH}_{2}-3$ exhibited long range coupling with each other $(J=2.3 \mathrm{~Hz})$, as is typical for the methylene units of a dihydroisobenzofuran, and the dihydrofuran subunit accounted for the last degree of unsaturation required for $\mathbf{1}$. Observed correlations in the ${ }^{1} \mathrm{H}-{ }^{13} \mathrm{C}$ HMBC spectrum for $\mathrm{H}-1$ with C-3, C-3a, and C-7, H-4 with C-3 and C-7a, H-6 with $\mathrm{C}-4$ and $\mathrm{C}-7 \mathrm{a}$, the protons of $7-\mathrm{O}-\mathrm{CH}_{3}$ with $\mathrm{C}-7$, and of $5-\mathrm{OH}$ with C-4 and C-6 (Figure 3) were used to determine the substitution pattern for the aromatic ring. Altogether, this established the structure of $\mathbf{1}$ as 7-methoxy-1,3dihydroisobenzofuran-5-ol, a new fungal natural product here named cymopolyphenol A, which is a methoxy analog of the 1,3-dihydroisobenzofuran-4,6-diol previously reported from Neolentinus lepideus (Li et al., 2013).

Compound 2 was also obtained as a white powder. The molecular formula of $\mathbf{2}$ was determined to have two less hydrogen atoms and one more oxygen than $\mathbf{1}$, or $\mathrm{C}_{9} \mathrm{H}_{8} \mathrm{O}_{4}$, after observation of the proton adduct peak in the HRESIMS spectrum at $m / z 181.0500[\mathrm{M}+\mathrm{H}]^{+}$(calcd. for $\mathrm{C}_{9} \mathrm{H}_{9} \mathrm{O}_{4}$, 181.0495). This formula requires six degrees of unsaturation, which is one more than $\mathbf{1}$ has. The ${ }^{1} \mathrm{H}$ and ${ }^{13} \mathrm{C}$ NMR spectra of 2 resemble those of 1 , except that the absence of one oxygenated methylene group accompanied the addition of a carbonyl at $\delta_{\mathrm{C}} 170.8(\mathrm{C}-1)$ for 2 (note that different carbon numbering schemes emerged for $\mathbf{1}$ and $\mathbf{2}$ due to the priority

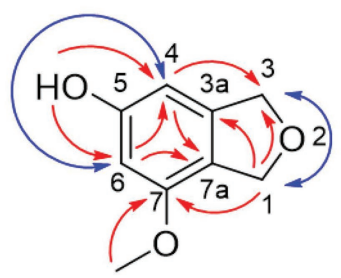

1

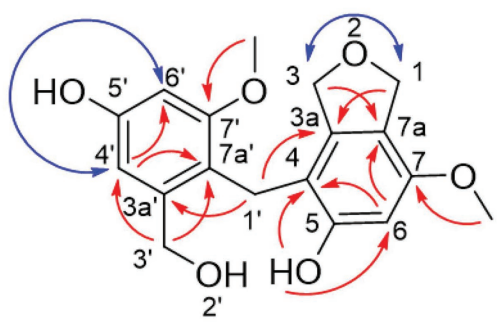

4

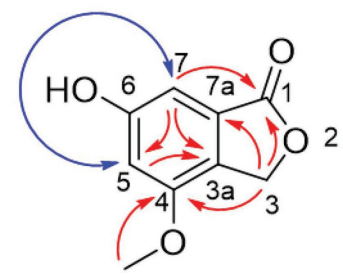

2

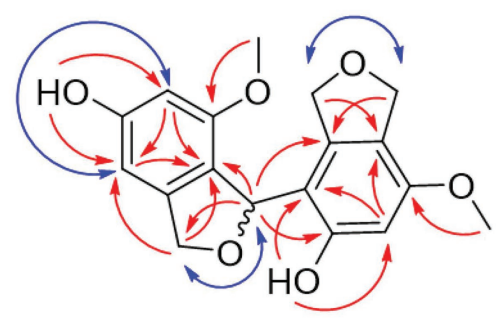

5

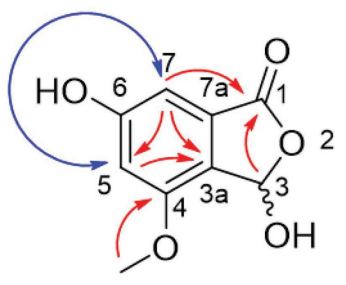

3

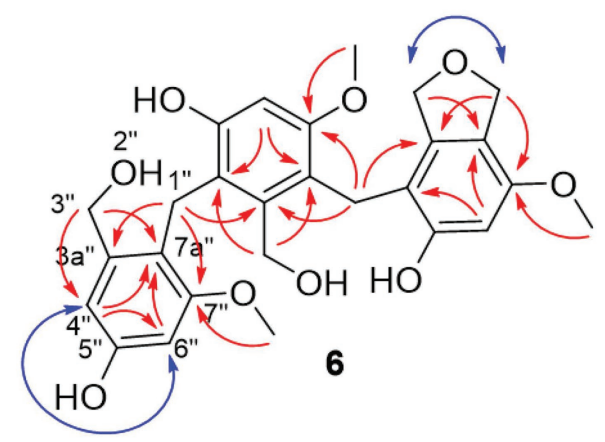

\section{$\frown{ }^{1} \mathrm{H}_{-}{ }^{13} \mathrm{C} H M B C \quad \curvearrowleft{ }^{1} \mathrm{H}_{-}{ }^{1} \mathrm{H}$ COSY}

FIGURE 3 | Selected correlations used to determine the planar structures of cymopolyphenols A-F (1-6). Red single-sided arrows represent cross peaks from the ${ }^{1} \mathrm{H}-{ }^{13} \mathrm{C}$ HMBC spectrum. Blue double-sided arrows show protons correlated in the ${ }^{1} \mathrm{H}-{ }^{1} \mathrm{H}$ COSY spectrum, and long-range $\mathrm{J}$ coupling that was determined for each from the ${ }^{1} \mathrm{H}$ spectrum. 
of this carbonyl), and the long range coupling observed for $\mathrm{CH}_{2}-1$ in $\mathbf{1}$ was not observed for the corresponding $\mathrm{CH}_{2}-3$ in 2 (Table 1). The ${ }^{1} \mathrm{H}-{ }^{13} \mathrm{C}$ HSQC and HMBC spectra of 1 and 2 were also similar, and key correlations from $\mathrm{H}-3$ to $\mathrm{C}-4$ and $\mathrm{H}-7$ to $\mathrm{C}-1$ (Figure 3) led to the structure elucidation of $\mathbf{2}$ as an analog of $\mathbf{1}$ with $\mathrm{C}-3$ being oxidized to an ester carbonyl and re-numbered as $\mathrm{C}-1$. The incremented oxidation state of $\mathrm{C}-1$ in 2 satisfied the difference in molecular formula and the corresponding additional unsaturation required compared to $\mathbf{1}$, as well as an observed respective upfield shift of C-7a and downfield shifts of $\mathrm{H}-7, \mathrm{C}-3 \mathrm{a}, \mathrm{C}-5$, and C-7. It was considered that the alternative position on the hydrofuran ring in 2 might instead be the oxidized carbon in the furan-1(3H)-one ring, if some 4-bond $\mathrm{HMBC}$ correlations were observed. However, the corresponding compound with $\mathrm{C}-1$ bearing the lactone carbonyl adjacent the methoxy group rather than the phenyl proton has been reported in the literature as an intermediate in the total synthesis of notholaenic acid, and this alternative compound (measured in the same NMR solvent) has spectroscopic data that is distinct from 2 (El-Feraly et al., 1985). Thus compound 2 was established as 6-hydroxy-4methoxyisobenzofuran-1(3H)-one, a new fungal natural product congener of the sparalides reported from Sparassis crispa (Wulf.) (Bang et al., 2017), here named as cymopolyphenol B.

Compound 3 was purified in crystalline form as colorless prisms. The molecular formula for this compound was obtained as $\mathrm{C}_{9} \mathrm{H}_{8} \mathrm{O}_{5}$ due to the proton adduct peak observed in the HRESIMS at $m / z 197.0453[\mathrm{M}+\mathrm{H}]^{+}$(calcd. for $\mathrm{C}_{9} \mathrm{H}_{9} \mathrm{O}_{5}$, 197.0444). Compared with compound 2 , this requires the same six degrees of unsaturation but one additional oxygen atom. The NMR data of $\mathbf{2}$ and $\mathbf{3}$ are quite similar (Table 1), with the noteworthy difference being that the oxygenated methylene of $2\left(\delta_{\mathrm{H}} 5.23, \delta_{\mathrm{c}} 68.0 ; \mathrm{CH}_{2}-3\right)$ was absent in 3 , and instead a significantly deshielded oxygenated methine group was observed $\left(\delta_{\mathrm{H}} 6.44, \delta_{\mathrm{c}} 102.0 ; \mathrm{CH}-3\right)$. The HSQC and ${ }^{1} \mathrm{H}_{-}{ }^{13} \mathrm{C}$ HMBC spectra of 2 and 3 were also otherwise similar, and key correlations from $\mathrm{H}-3$ to $\mathrm{C}-1$ and $\mathrm{H}-7$ to $\mathrm{C}-1$ (Figure 3) led to the structure elucidation of 3 as an analog of 2 with C-3 being oxidized as a hemiacetal. Since this compound was obtained in crystalline form and is relatively devoid of signals in the ${ }^{1} \mathrm{H}$ NMR spectrum, it was decided to investigate the configuration of C-3 by X-ray crystallography rather than using a Mosher ester analysis. The crystallographic study of $\mathbf{3}$ confirmed the planar structure of this molecule (Figure 4). It was also found that this material was obtained in crystalline form as a racemic mixture, as indicated by the non-centrosymmetric space group $C c$ that would be invalid if 3 were enantio-pure (Parsons, 2017). The optical rotation measured for $3\left\{[\alpha]_{\mathrm{D}}^{25}(c 0.1, \mathrm{MeOH})\right\}$ was also zero, further supporting the assignment of the racemic mixture. This likely resulted from keto-enol tautomerization or lactone ring opening and re-closure in solution and during the extraction and purification process rather than non-stereospecific biosynthesis. The instability of $\mathbf{3}$ was further noted with the observation of an impurity of the proposedly 3-O-methyl analog in the NMR spectra measured first in $\mathrm{CD}_{3} \mathrm{OD}$ (then diluted in $\mathrm{MeOH}$ for sample transfer) and later in DMSO- $d_{6}$, since corresponding peaks were not in the HRESIMS, nor was this impurity observed in the same sample by X-ray crystallography. The new natural product, $\mathbf{3}$, was in summary established as 3,6-dihydroxy-4-methoxyisobenzofuran-1(3H)-one, here named as cymopolyphenol C.

Compound 4 was afforded in crystalline form as colorless prisms. The molecular formula was determined to be $\mathrm{C}_{18} \mathrm{H}_{20} \mathrm{O}_{6}$ from its sodium adduct peak at $\mathrm{m} / z 355.1159[\mathrm{M}+\mathrm{Na}]^{+}$(calcd. for $\mathrm{C}_{18} \mathrm{H}_{20} \mathrm{O}_{6} \mathrm{Na}$, 355.1152) in the HRESIMS. This formula calls for nine degrees of unsaturation. The ${ }^{1} \mathrm{H}$ and ${ }^{13} \mathrm{C}$ NMR data (Table 2) revealed that 4 possesses two methoxy groups $\left(\delta_{\mathrm{H}}\right.$ $3.678, \delta_{\mathrm{C}} 54.9 ; 7-\mathrm{O}-\mathrm{CH}_{3}$; and $\left.\delta_{\mathrm{H}} 3.682, \delta_{\mathrm{C}} 55.3 ; 7^{\prime}-\mathrm{O}-\mathrm{CH}_{3}\right)$, one aliphatic methylene $\left(\delta_{\mathrm{H}} 3.674, \delta_{\mathrm{C}} 21.1 ; \mathrm{CH}_{2}-1\right)$, three oxygenated methylenes $\left(\delta_{\mathrm{H}} 4.70, \delta_{\mathrm{C}} 70.3 ; \mathrm{CH}_{2}-1, \delta_{\mathrm{H}} 4.16, \delta_{\mathrm{C}} 71.8 ; \mathrm{CH}_{2}-3\right.$, and $\left.\delta_{\mathrm{H}} 4.23, \delta_{\mathrm{C}} 60.0 ; \mathrm{CH}_{2}-3^{\prime}\right)$, three aromatic methines $\left(\delta_{\mathrm{H}} 6.37\right.$, $\delta_{\mathrm{C}}$ 97.7; CH-6, $\delta_{\mathrm{H}} 6.52, \delta_{\mathrm{C}} 105.3 ; \mathrm{CH}-4$ and $\delta_{\mathrm{H}} 6.28, \delta_{\mathrm{C}} 96.9 ;$ $\left.\mathrm{CH}-6^{\prime}\right)$, and nine nonprotonated $\mathrm{sp}^{2}$ carbons $\left[\delta_{\mathrm{C}} 139.5\right.$ (C-3a), 112.8 (C-4), 155.6 (C-5), 151.4 (C-7), 116.4 (C-7a), 143.3 (C-3a'), $156.7\left(\mathrm{C}^{-} 5^{\prime}\right), 158.2\left(\mathrm{C}-7^{\prime}\right)$, and $\left.114.2\left(\mathrm{C}-7 \mathrm{a}^{\prime}\right)\right]$. From the NMR data, several key features from compounds 1-3 were observed in 4. The HMBC correlations from $\mathrm{H}-1$ to C-3a, from $\mathrm{H}-3$ to $\mathrm{C}-7 \mathrm{a}$, from $5-\mathrm{OH}$ to $\mathrm{C}-4$ and $\mathrm{C}-6$, from $\mathrm{H}-6$ to $\mathrm{C}-4$ and $\mathrm{C}-7 \mathrm{a}$, and $7-\mathrm{O}-\mathrm{CH}_{3}$ to $\mathrm{C}-7$, together with the long-range spin system of $\mathrm{H}-1$ and $\mathrm{H}-3 \quad(J=2.4 \mathrm{~Hz})$ indicated a
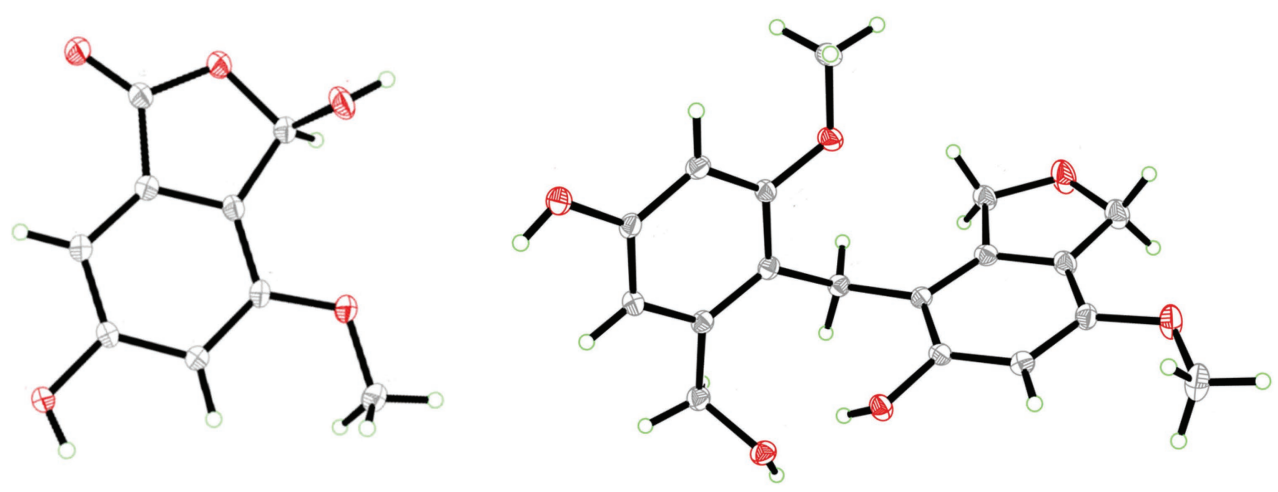

FIGURE 4 | X-ray ORTEP drawings of compounds $\mathbf{3}$ (left) and $\mathbf{4}$ (right). 
7-methoxy-1,3-dihydroisobenzofuran-5-ol moiety in 4. Inspection of the remaining NMR signals led to the establishment of a related tetra-substituted phenolic moiety that is representative of a ring opening between $\mathrm{C}-1$ and $\mathrm{O}-2$ in the dihydrofuran subunit of compound $\mathbf{1}$, here presumed to be a monomeric subunit of 4 . The open-ring and closed-ring subunits mentioned above were determined to be connected from methylene C-1' to the nonprotonated aromatic $\mathrm{C}-4$, with evidence of $\mathrm{HMBC}$ correlations from $\mathrm{H}-1$ ' to both $\mathrm{C}-3 \mathrm{a}$ and $\mathrm{C}-3 \mathrm{a}$.' The structure of 4 was thus established as a homodimer of 7-methoxy-1,3dihydroisobenzofuran-5-ol (1) with ring opening between C-1' and O-2'. Compound 4 is here named as cymopolyphenol D, systematically 4-[4-hydroxy-2-(hydroxymethyl)-6-methoxybenzyl]7-methoxy-1,3-dihydroisobenzofuran-5-ol. The structure of this new natural product was further confirmed by single-crystal $\mathrm{X}$-ray diffraction analysis (Figure 4).

Compound $\mathbf{5}$ was isolated as a light-brown powder. The molecular formula of 5 was established as $\mathrm{C}_{18} \mathrm{H}_{18} \mathrm{O}_{6}$ based on a sodium adduct peak observed in the HRESIMS at $m / z 353.0997$ $[\mathrm{M}+\mathrm{Na}]^{+}$(calcd. for $\mathrm{C}_{18} \mathrm{H}_{18} \mathrm{O}_{6} \mathrm{Na}$, 353.0996). This formula requires 10 degrees of unsaturation, or one more than for the structure of 4. Comparison of the ${ }^{1} \mathrm{H}$ and ${ }^{13} \mathrm{C}$ NMR data (Table 2) for 5 with those of $\mathbf{4}$ showed strong similarities except for the presence in $\mathbf{5}$ of one additional oxymethine $\left(\delta_{\mathrm{H}}\right.$ 6.41, $\delta_{\mathrm{C}} 76.4 ; \mathrm{C}-1$ ) that accompanied the absence of an aliphatic methylene from 4. Furthermore, the oxymethine C-1' exhibited long range coupling $(J=3.0,1.9 \mathrm{~Hz})$ with the diastereotopic protons of oxymethylene C- $3^{\prime}\left[\delta_{\mathrm{H}} 5.00(\mathrm{dd}, J=12.4,3.0 \mathrm{~Hz})\right.$ and $\left.4.84(\mathrm{dd}, J=12.4,1.9 \mathrm{~Hz}), \delta_{\mathrm{C}} 72.4\right]$, which was consistent with the protons of $\mathrm{C}-1$ and $\mathrm{C}-3$ coupling in compounds 1 and 4, while the corresponding groups (C-1' and $\left.\mathrm{C}-3^{\prime}\right)$ were not coupled and were observed as singlets in 4 (Figure 3). It was accordingly suggested that $\mathbf{5}$ is an analog of $\mathbf{4}$, and another homodimer of $\mathbf{1}$, but with both dihydroisobenzofuran subunits intact. This proposal accounted for the additional degree of unsaturation required for $\mathbf{5}$, and was further supported in concept and attachment point by the HMBC correlations from $\mathrm{H}-1^{\prime}$ to C-3a, C-5, and C-7a'. Therefore, the structure of 5 was established as a new homodimer of 7-methoxy-1,3dihydroisobenzofuran-5-ol (1), as shown. Since C-1' is a chiral center, the optical rotation of $\mathbf{5}$ was measured, and this compound was found to be racemic $\left.\left\{[\alpha]_{\mathrm{D}}^{25} 0(c) 0.1, \mathrm{MeOH}\right)\right\}$. It was attempted to purify the enantiomers of 5 by HPLC using a chiral column, but the completely resolved separated peaks were found upon reinjection to have undergone racemization in solution. Accordingly, this racemic mixture (5) was assigned the common name cympolyphenol $\mathrm{E}$ and systematic name 7,7'-dimethoxy-1,1',3,3'-tetrahydro-[1,4'-biisobenzofuran]-5,5'-diol.

Compound 6 was obtained as a white powder and found to have the molecular formula $\mathrm{C}_{27} \mathrm{H}_{30} \mathrm{O}_{9}$ based on the observed sodium adduct peak at $\mathrm{m} / z 521.1790$ in the HRESIMS (calcd. For $\left.\mathrm{C}_{27} \mathrm{H}_{30} \mathrm{O}_{9} \mathrm{Na}, 521.1782\right)$. The NMR data of 6 had the hallmarks of both 4 and 5 (Table 2), and indicated the presence of one 7-methoxy-1,3-dihydroisobenzofuran-5-ol and two 3-(hydroxymethyl)-5-methoxyphenol moieties as monomeric substructures presumably all derived from $\mathbf{1}$. The structural subunits were able to be connected unequivocally from $\mathrm{C}-1$ ' to $\mathrm{C}-4$ and $\mathrm{C}-1$ " to $\mathrm{C}-4$ ' by the observation of $\mathrm{HMBC}$ correlations from $\mathrm{H}-1^{\prime}$ to $\mathrm{C}-3 \mathrm{a}, \mathrm{C}-3 \mathrm{a}^{\prime}$, and $\mathrm{C}-7^{\prime}$ along with those from H-1" to C-3a', C-3a", and C-7" (Figure 3). The structure of $\mathbf{6}$ was thus established as a homotrimer of 7-methoxy-1,3-dihydroisobenzofuran-5-ol (1), with one intact dihydroisobenzofuran moiety at the terminal monomeric subunit, as shown. This achiral molecule was assigned the common name of cymopolyphenol F, or 4-(4-hydroxy-3-(4-hydroxy2-(hydroxymethyl)-6-methoxybenzyl)-2-(hydroxymethyl)-6methoxybenzyl)-7-methoxy-1,3-dihydroisobenzofuran-5-ol.

It was considered whether compounds 4-6, representing low-order polymers of $\mathbf{1}$, might be extraction artifacts as opposed to biosynthetic products of fungal metabolism. These molecules could be biosynthesized de novo, using $\mathbf{1}$ as an intermediate, through radical coupling, or by acid/base reactions via a quinone methide pathway catalyzed by fungal enzymes. Alternatively, the compounds might be generated incidentally by the extraction and isolation protocol. However, the corresponding LC-MS peaks for these compounds were observed in the crude extract prior to purification by the relatively harsher conditions of repeated chromatographic separation. Furthermore, preliminary attempts to chemically synthesize compounds 4-6 from $\mathbf{1}$ at identical medium PDB used in scale-up fermentation, acid $(\mathrm{pH}=4.0)$ and base $(\mathrm{pH}=10.0)$ solvents at $28^{\circ} \mathrm{C}$ with agitation $(120 \mathrm{rpm})$ for 15 days were unsuccessful.

Compounds $\mathbf{7}$ and $\mathbf{8}$ were identified as previously described molecules, respectively F1839-I and stachybotrylactone, by comparison of obtained NMR, MS, and optical rotation data with literature values (Ayer and Miao, 1993; Sakai et al., 1995; Zhao et al., 2017). Interestingly, stachybotrylactone was established at the time of its discovery as a spontaneous Cannizzaro reaction degradation product of the related molecule, stachybotrydial (Ayer and Miao, 1993). However, this known phenylspirodrimane fungal natural product contains as a substructure one of the new molecules here reported, 2.

\section{Biological Evaluation}

Compound 2 was not obtained in sufficient quantity for biological testing in the present study. However, the purified compounds $\mathbf{1}$ and 3-8 were tested in vitro with a small array of bioassays to evaluate their potential for use in medicine, agriculture, aquaculture, or other biotechnology applications. For example, in vitro against the U87 human glioblastoma and CCRF-CEM human $\mathrm{T}$ lymphoblast cell lines, none of the tested compounds were found to be antiproliferative or cytotoxic $\left(\mathrm{IC}_{50}>20 \mu \mathrm{M}\right)$. Accordingly, these compounds were evaluated for activity against an array of aquatic and human pathogens including Gram-negative and Gram-positive bacteria: P. carrageenovora, V. shilanii, V. scophthalmi, V. alginolyticus, S. typhi, P. aeruginosa, S. aureus, and $B$. pumilus. Compounds $\mathbf{1}$ and 3-6 were found to be weakly antimicrobial (MIC 16-64 $\mu \mathrm{g} / \mathrm{ml}$ ) in vitro against some of these pathogens, as detailed in Table 3. While these compounds are not active against the human pathogens at concentrations with pharmaceutical relevance, it is of interest to find selective agents for the potential treatment of aquatic 
TABLE 3 | In vitro antimicrobial activity observed for $\mathbf{1}$ and $\mathbf{3 - 8 .}$

\begin{tabular}{|c|c|c|c|c|c|c|c|c|}
\hline \multirow[t]{2}{*}{ Cpd } & \multicolumn{8}{|c|}{ Minimum inhibition concentration (MIC, $\mu \mathrm{g} / \mathrm{ml}$ ) } \\
\hline & $\begin{array}{c}\text { Pseudoalteromonas } \\
\text { carrageenovora }\end{array}$ & Vibrio shilanii & $\begin{array}{c}\text { Vibrio } \\
\text { scophthalmi }\end{array}$ & $\begin{array}{c}\text { Vibrio } \\
\text { alginolyticus }\end{array}$ & $\begin{array}{l}\text { Salmonella } \\
\text { typhi }\end{array}$ & $\begin{array}{c}\text { Pseudomonas } \\
\text { aeruginosa }\end{array}$ & $\begin{array}{l}\text { Staphylococcus } \\
\text { aureus }\end{array}$ & Bacillus pumilus \\
\hline 1 & $>64$ & $>64$ & $>64$ & 64 & $>64$ & $>64$ & $>64$ & $>64$ \\
\hline 3 & 32 & $>64$ & 64 & 64 & 32 & 64 & $>64$ & $>64$ \\
\hline 4 & 32 & 32 & 32 & 64 & 64 & 64 & $>64$ & $>64$ \\
\hline 7 & $>64$ & $>64$ & $>64$ & $>64$ & $>64$ & $>64$ & $>64$ & $>64$ \\
\hline 8 & $>64$ & $>64$ & $>64$ & $>64$ & $>64$ & $>64$ & $>64$ & $>64$ \\
\hline $\mathbf{P C}^{a}$ & 0.5 & 1 & 2 & 1 & 1 & 1 & 1 & 1 \\
\hline $\mathbf{N C}^{b}$ & $>64$ & $>64$ & $>64$ & $>64$ & $>64$ & $>64$ & $>64$ & $>64$ \\
\hline
\end{tabular}

aPC: norfloxacin, used as a positive control. The MIC of this compound was not tested below $0.5 \mu \mathrm{g} / \mathrm{ml}$ in this experiment, but it has been shown to be active $\leq 0.125 \mu \mathrm{g} / \mathrm{ml}$ in all organisms tested by the same experiment conducted at a different time.

${ }^{b} \mathrm{NC}$ : blank media, used as a negative control.

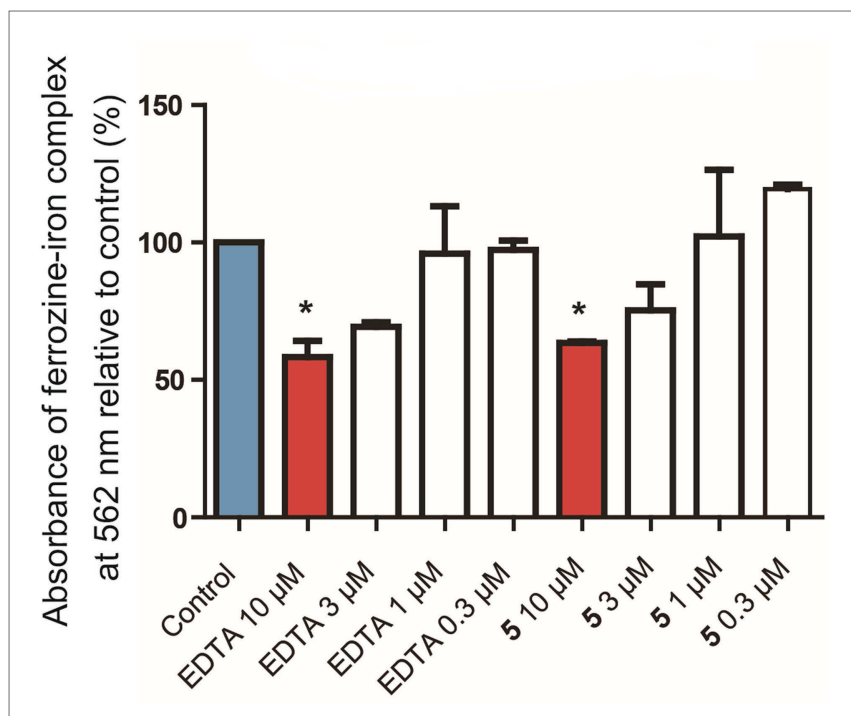

FIGURE 5 | In vitro chelation of 5 to $\mathrm{Fe}^{2+}$ in a ferrozine-based chemical assay. Control: Blank media, sodium acetate in water, used as a negative control. EDTA: Ethylenediaminetetraacetate, used as a positive control. ${ }^{*} p<0.05$ vs. control.

pathogens for use in preventing economic losses in the aquaculture industry without risking the induction of drug resistance in human pathogens. Compounds 4 and $\mathbf{6}$ were the most active tested against the aquatic pathogens, which may indicate an ecological role of these new natural products and potential direction for further development based on the same scaffolds.

Due to the amount of oxygen atoms in the isolated compounds, especially 4-6, it was considered whether these molecules could chelate iron. The chelation of iron by secondary metabolites has ecological implications, e.g., with siderophores, and can also play a role in various aspects of human health. For example, the deposition of iron in nerves causes oxidative stress and inflammation, leading to the kind of nerve damage that can be found in traumatic brain injury, Alzheimer's disease, and Parkinson's disease. When the pure molecules were tested in a ferrozine $\mathrm{Fe}^{2+}$ chelation chemical assay, it was found that compound 5 concentration-dependently chelated iron (Figure 5) with nearly the same efficacy at $10 \mu \mathrm{M}$ as the positive control, ethylenediaminetetraacetate (EDTA). Interestingly, compound 4 was inactive in the same assay at $10 \mu \mathrm{M}$. This suggests that while the flexibility afforded to 4 by its structural subunits being linked with the $\mathrm{C}-1$ ' methylene group rather than the C-1' dihydroisofuran methine in $\mathbf{5}$ may give it preferential antibacterial activity, the relatively locked conformation of 5 is more suitable for iron chelation. This also suggests that iron chelation is not the primary mechanism of antibiotic action of 4 .

Finally, the compounds were evaluated with an in vivo assay of inducing disease resistance in plants using the PR1::GUS transgenic model organism, A. thaliana. Pathogenesisrelated protein 1 (PR1) is correlated to plant disease resistance, and $\beta$-glucuronidase (GUS) is attached as a reporter gene (Van Loon, 1997; Koornneef et al., 2008). As shown in Figure 6, plants treated with compound 8 at $10 \mu \mathrm{M}$ were found to accumulate PR1, indicating the potential of this molecule to enhance plant disease resistance. The remaining compounds, including the close structural analog, 7, were not found to activate PR1 in the same test model at $10 \mu \mathrm{M}$. This newly discovered function of $\mathbf{8}$ merits further investigation of structurally related molecules in this and similar ecological studies.

\section{CONCLUSION}

From preliminary MS/MS-based molecular networking analysis of 80 extracts prepared from marine sponge-associated fungal cultures, half from shallow reefs and half from MCEs, it was found that the extracts of fungal strains prepared from mesophotic zone sponge samples contained different chemistry than their shallow water counterparts. It is hypothesized that this is a representative phenomenon that should encourage the further chemical investigation of mesophotic zone organisms, and the 


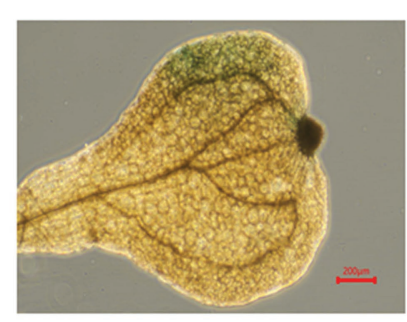

DMSO

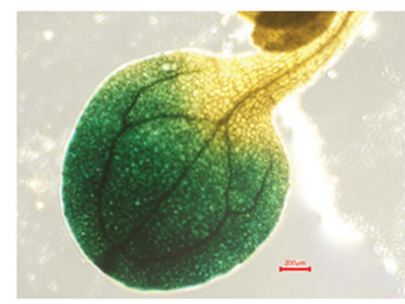

salicylic acid (1.0 mM)

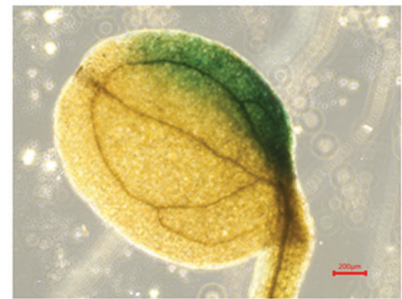

$810.0 \mu \mathrm{M}$

FIGURE 6 | In vivo activation of the GUS reporter in PR1::GUS transgenic Arabidopsis thaliana plants. DMSO was used as a negative control. Salicylic acid was used as a positive control.

purposeful generation and analysis of a larger data set is planned. The investigation of a prioritized Cymostachys fungus that was isolated from its association with a $103 \mathrm{~m}$ deep Aaptos sponge led to the discovery and structural characterization of a new series of compounds, cymopolyphenols A-F (1-6) along with the known fungal natural products F1839-I (7) and stachybotrylactone (8). Compounds $\mathbf{1 - 6}$ and 8 all contain a dihydroisobenzofuran skeleton, and 4-6 appear to be low-order polymers of $\mathbf{1}$ that present new scaffolds. Structural analogs of these compounds with different oxidation states, increased order of polymerization, and methylation patterns are predicted to emerge from future research on related organisms.

Compounds 1-6 are hydrogen deficient molecules, and each has a proton-to-heavy-atom ratio under 1 , yet the structures of these molecules were able to be established by spectroscopic and spectrometric data interpretation. This fortuitous occurrence was due in equal parts to the dispersion of signals in the ${ }^{1} \mathrm{H}$ NMR spectrum without significant overlapping, and the distribution of the associated hydrogen atoms throughout the molecules that allowed for informative long-range correlations to be observed. Still, further support for all the structures was garnered from the X-ray crystallographic study of 3 and 4. Compounds 1 and 3-6 were found to be weakly antimicrobial (MIC 16-64 $\mu \mathrm{g} / \mathrm{ml}$ ) in vitro against several Gram-positive and Gram-negative human or aquatic pathogens. These data are not suggestive of a meaningful lead for pharmaceutical development, but could potentially be useful in the development of aquaculture treatments or represent clues to an ecological role of the compounds.

\section{DATA AVAILABILITY STATEMENT}

The datasets presented in this study can be found in online repositories. The names of the repository/repositories and accession number(s) can be found in the article/ Supplementary Material.

\section{REFERENCES}

Agarwal, G., Carcache, P. J. B., Addo, E. M., and Kinghorn, A. D. (2020). Current status and contemporary approaches to the discovery of antitumor agents from higher plants. Biotechnol. Adv. 38:107337. doi: 10.1016/j. biotechadv.2019.01.004

\section{AUTHOR CONTRIBUTIONS}

All authors conceived the research, analyzed the data, contributed to the study, and approved the final version of the manuscript. TW, JZh, JZo, YS, PS, TY, XL, and JY carried out the experiments. $\mathrm{WZ}, \mathrm{WC}, \mathrm{XW}, \mathrm{XY}, \mathrm{CN}, \mathrm{JL}$, and $\mathrm{SH}$ revised the manuscript.

\section{FUNDING}

This study was supported by the National Key Research and Development Program of China, funded through MOST (the Ministry of Science and Technology of China; grant 2018YFC0310900 to XY, CN, and SH), NSFC (the National Natural Science Foundation of China; grant 41906093 to TW, 41776168 to $\mathrm{SH}$, and 81850410553 and 82050410451 to $\mathrm{CN}$ ), the Natural Science Foundation of Zhejiang Province (grant LGF21D060003 to TW), Ningbo Public Service Platform for High-Value Utilization of Marine Biological Resources (grant NBHY-2017-P2 to SH), Research Fund for Science in Ningbo University (XYL20021 to TW), the National 111 Project of China (D16013), and the Li Dak Sum Yip Yio Chin Kenneth Li Marine Biopharmaceutical Development Fund of Ningbo University.

\section{ACKNOWLEDGMENTS}

We are grateful to Ting Han from Blue Flag Diving Club, for technical diving and collection of the sponges used for mycology in this research.

\section{SUPPLEMENTARY MATERIAL}

The Supplementary Material for this article can be found online at: https://www.frontiersin.org/articles/10.3389/fmicb.2021.638610/ full\#supplementary-material

Ayer, W. A., and Miao, S. (1993). Secondary metabolites of the aspen fungus Stachybotrys cylindrospora. Can. J. Chem. 71, 487-493. doi: 10.1139/v93-069 Azran, S., Danino, O., Förster, D., Kenigsberg, S., Reiser, G., Dixit, M., et al. (2015). Identification of highly promising antioxidants/neuroprotectants based on nucleoside 5'-phosphorothioate scaffold. Synthesis, activity, and 
mechanisms of action. J. Med. Chem. 58, 8427-8443. doi: 10.1021/acs. jmedchem.5b00575

Bang, S., Chae, H. S., Lee, C., Choi, H. G., Ryu, J., Li, W., et al. (2017). New aromatic compounds from the fruiting body of Sparassis crispa (Wulf.) and their inhibitory activities on proprotein convertase subtilisin/kexin type 9 mRNA expression. J. Agric. Food Chem. 65, 6152-6157. doi: 10.1021/acs. jafc.7b02657

Bibi, F., Yasir, M., Al-Sofyani, A., Naseer, M. I., and Azhar, E. I. (2020). Antimicrobial activity of bacteria from marine sponge Suberea mollis and bioactive metabolites of Vibrio sp. EA348. Saudi. J. Biol. Sci. 27, 1139-1147. doi: 10.1016/j.sjbs.2020.02.002

Boudreau, P. D., Byrum, T., Liu, W. T., Dorrestein, P. C., and Gerwick, W. H. (2012). Viequeamide A, a cytotoxic member of the kulolide superfamily of cyclic depsipeptides from a marine button Cyanobacterium. J. Nat. Prod. 75, 1560-1570. doi: 10.1021/np300321b

CLSI (2018). Methods for dilution antimicrobial susceptibility tests for bacteria that grow aerobically. 11th Edn. Wayne, PA: Clinical and Laboratory Standards Institute.

Cragg, G. M., Grothaus, P. G., and Newman, D. J. (2009). Impact of natural products on developing new anti-cancer agents. Chem. Rev. 109, 3012-3043. doi: $10.1021 / \mathrm{cr} 900019 \mathrm{j}$

Da Lozzo, E. J., Mangrich, A. S., Rocha, M. E. M., de Oliveira, M. B. M., and Carnieri, E. G. S. (2002). Effects of citrinin on iron-redox cycle. Cell Biochem. Funct. 20, 19-29. doi: 10.1002/cbf.931

El-Feraly, F. S., Cheatham, S. F., and McChesney, J. D. (1985). Total synthesis of notholaenic acid. J. Nat. Prod. 48, 293-298. doi: 10.1021/np50038a015

Henríquez, M., Vergara, K., Norambuena, J., Beiza, A., Maza, F., Ubilla, P., et al. (2014). Diversity of cultivable fungi associated with Antarctic marine sponges and screening for their antimicrobial, antitumoral and antioxidant potential. World J. Microbiol. Biotechnol. 30, 65-76. doi: 10.1007/ s11274-013-1418-X

Hirata, Y., and Uemura, D. (1986). Halichondrins-antitumor polyether macrolides from a marine sponge. Pure Appl. Chem. 58, 701-710. doi: 10.1351/ pac198658050701

Höller, U., Wright, A. D., Matthee, G. F., Konig, G. M., Draeger, S., Aust, H. J., et al. (2000). Fungi from marine sponges: diversity, biological activity and secondary metabolites. Mycol. Res. 104, 1354-1365. doi: 10.1017/ S0953756200003117

Jagels, A., Lindemann, V., Ulrich, S., Gottschalk, C., Cramer, B., Hübner, F., et al. (2019). Exploring secondary metabolite profiles of Stachybotrys spp. by LC-MS/MS. Toxins 11:133. doi: 10.3390/toxins 11030133

Keller, N. P. (2019). Fungal secondary metabolism: regulation, function and drug discovery. Nat. Rev. Microbiol. 17, 167-180. doi: 10.1038/ s41579-018-0121-1

Koornneef, A., Verhage, A., Leon-Reyes, A., Snetselaar, R., Van Loon, L. C., and Pieterse, C. M. J. (2008). Towards a reporter system to identify regulators of cross-talk between salicylate and jasmonate signaling pathways in Arabidopsis. Plant Signal. Behav. 3, 543-546. doi: 10.4161/psb.3.8.6151

Lachance, H., Wetzel, S., Kumar, K., and Waldmann, H. (2012). Charting, navigating, and populating natural product chemical space for drug discovery. J. Med. Chem. 55, 5989-6001. doi: 10.1021/jm300288g

Le Goff, G., Lopes, P., Arcile, G., Vlachou, P., Van Elslande, E., Retailleau, P., et al. (2019). Impact of the cultivation technique on the production of secondary metabolites by Chrysosporium lobatum TM-237-S5, isolated from the sponge Acanthella cavernosa. Mar. Drugs 17:678. doi: 10.3390/ $\operatorname{md} 17120678$

Lesser, M. P., Slattery, M., and Mobley, C. D. (2018). Biodiversity and functional ecology of mesophotic coral reefs. Annu. Rev. Ecol. Evol. Syst. 49, 49-71. doi: 10.1146/annurev-ecolsys-110617-062423

Letsiou, S., Bakea, A., Le Goff, G., Lopes, P., Gardikis, K., Weis, M., et al. (2020). Marine fungus Aspergillus chevalieri TM2-S6 extract protects skin fibroblasts from oxidative stress. Mar. Drugs 18:460. doi: 10.3390/md18090460

Li, Y. X., Bao, L., Song, B., Han, J. J., Li, H. R., Zhao, F., et al. (2013). A new benzoquinone and a new benzofuran from the edible mushroom Neolentinus lepideus and their inhibitory activity in NO production inhibition assay. Food Chem. 141, 1614-1618. doi: 10.1016/j.foodchem.2013.04.133

Li, Q., and Wang, G. (2009). Diversity of fungal isolates from three Hawaiian marine sponges. Microbiol. Res. 164, 233-241. doi: 10.1016/j.micres.2007. 07.002
Lin, C. G., McKenzie, E. H. C., Bhat, D. J., Ran, S. F., Chen, Y., Hyde, K. D., et al. (2016). Stachybotrys-like taxa from karst areas and a checklist of Stachybotrys-like species from Thailand. Mycosphere 7, 1273-1291. doi: 10.5943/mycosphere/7/9/3

Liu, N., Peng, S., Yang, J., Cong, Z., Lin, X., Liao, S., et al. (2019). Structurally diverse sesquiterpenoids and polyketides from a sponge-associated fungus Aspergillus sydowii SCSIO41301. Fitoterapia 135, 27-32. doi: 10.1016/j. fitote.2019.03.031

Lombard, L., Houbraken, J., Decock, C., Samson, R. A., Meijer, M., Réblová, M., et al. (2016). Generic hyper-diversity in Stachybotriaceae. Persoonia Mol. Phylogeny Evol. Fungi 36, 156-246. doi: 10.3767/003158516X691582

Machida, K., Abe, T., Arai, D., Okamoto, M., Shimizu, I., de Voogd, N. J., et al. (2014). Cinanthrenol A, an estrogenic steroid containing phenanthrene nucleus, from a marine sponge Cinachyrella sp. Org. Lett. 16, 1539-1541. doi: $10.1021 / \mathrm{ol} 5000023$

Mayer, A. M. S., Guerrero, A. J., Rodríguez, A. D., Taglialatela-Scafati, O., Nakamura, F., and Fusetani, N. (2020). Marine pharmacology in 2014-2015: Marine compounds with antibacterial, antidiabetic, antifungal, antiinflammatory, antiprotozoal, antituberculosis, antiviral, and anthelmintic activities; affecting the immune and nervous systems, and other miscellaneous mechanisms of action. Mar. Drugs 18:5. doi: 10.3390/md18010005

McCauley, E. P., Piña, I. C., Thompson, A. D., Bashir, K., Weinberg, M., Kurz, S. L., et al. (2020). Highlights of marine natural products having parallel scaffolds found from marine-derived bacteria, sponges, and tunicates. J. Antibiot. 73, 504-525. doi: 10.1038/s41429-020-0330-5

Newman, D. J., and Cragg, G. M. (2020). Natural products as sources of new drugs over the nearly four decades from 01/1981 to 09/2019. J. Nat. Prod. 83, 770-803. doi: 10.1021/acs.jnatprod.9b01285

Nikolaivits, E., Agrafiotis, A., Termentzi, A., Machera, K., Le Goff, G., Álvarez, P., et al. (2019). Unraveling the detoxification mechanism of 2,4-dichlorophenol by marine-derived mesophotic symbiotic fungi isolated from marine invertebrates. Mar. Drugs 17:564. doi: 10.3390/md17100564

Olson, J. B., and Kellogg, C. A. (2010). Microbial ecology of corals, sponges, and algae in mesophotic coral environments. FEMS Microbiol. Ecol. 73, 17-30. doi: 10.1111/j.1574-6941.2010.00862.x

Parsons, S. (2017). Determination of absolute configuration using X-ray diffraction. Tetrahedron Asymmetry 28, 1304-1313. doi: 10.1016/j.tetasy.2017. 08.018

Pedrosa, R., Gaudêncio, P. S., and Vasconcelos, V. (2020). XVI international symposium on marine natural products |XI European conference on marine natural products. Mar. Drugs 18:40. doi: 10.3390/md18010040

Pyle, R. L., and Copus, J. M. (2019). "Mesophotic coral ecosystems: introduction and overview" in Mesophotic coral ecosystems. eds. Y. Loya, K. A. Puglise and T. Bridge (Springer: New York), 3-27.

Rocha, L. A., Pinheiro, H. T., Shepherd, B., Papastamatiou, Y. P., Luiz, O. J., Pyle, R. L., et al. (2018). Mesophotic coral ecosystems are threatened and ecologically distinct from shallow water reefs. Science 361, 281-284. doi: 10.1126/science.aaq1614

Sakai, K., Watanabe, K., Masuda, K., Tsuji, M., Hasumi, K., and Endo, A. (1995). Isolation, characterization and biological activities of novel triprenyl phenols as pancreatic cholesterol esterase inhibitors produced by Stachybotrys sp. F-1839. J. Antibiot. 48, 447-456. doi: 10.7164/antibiotics.48.447

Schupp, P. J., Kohlert-Schupp, C., Whitefield, S., Engemann, A., Rohde, S. Hemscheidt, T., et al. (2009). Cancer chemopreventive and anticancer evaluation of extracts and fractions from marine macro- and micro-organisms collected from twilight zone waters around Guam. Nat. Prod. Commun. 4, 1717-1728. doi: $10.1177 / 1934578 X 0900401222$

Sinniger, F., Ballantine, D. L., Bejarano, I., Colin, P. L., Pochon, X., Pomponi, S. A., et al. (2016). "Biodiversity of mesophotic coral ecosystems" in Mesophotic coral ecosystems - A lifeboat for coral reefs? eds. E. K. Baker, K. Puglise and P. Harris (Arendal, Nairobi and Arendal: The United Nations Environment Programme and GRID), 50-62.

Still, P. C., Johnson, T. A., Theodore, C. M., Loveridge, S. T., and Crews, P. (2014). Scrutinizing the scaffolds of marine biosynthetics from different source organisms: Gram-negative cultured bacterial products enter center stage. J. Nat. Prod. 77, 690-702. doi: 10.1021/np500041x

Suffness, M., and Douros, J. D. (1981). Discovery of antitumor agents from natural sources. Trends Pharmacol. Sci. 2, 307-310. doi: 10.1016/ 0165-6147(81)90349-7 
Van Loon, L. C. (1997). Induced resistance in plants and the role of pathogenesisrelated proteins. Eur. J. Plant Pathol. 103, 753-765. doi: 10.1023/ A: 1008638109140

Wang, M., Carver, J. J., Phelan, V. V., Sanchez, L. M., Garg, N., Peng, Y., et al. (2016). Sharing and community curation of mass spectrometry data with Global Natural Products Social Molecular Networking. Nat. Biotechnol. 34, 828-837. doi: 10.1038/nbt.3597

Wang, A., Xu, Y., Gao, Y., Huang, Q., Luo, X., An, H., et al. (2015). Chemical and bioactive diversities of the genera Stachybotrys and Memnoniella secondary metabolites. Phytochem. Rev. 14, 623-655. doi: 10.1007/s11101-014-9365-1

Wang, S., Zheng, Y., Gu, C., He, C., Yang, M., Zhang, X., et al. (2018). Bacillus cereus AR156 activates defense responses to Pseudomonas syringae pv tomato in Arabidopsis thaliana similarly to flg22. Mol. Plant-Microbe Interact. 31, 311-322. doi: 10.1094/MPMI-10-17-0240-R

Weiss, K. R. (2017). Into the twilight zone. Science 355, 900-904. doi: 10.1126/ science.355.6328.900

Williams, R. B., Martin, S. M., Lawrence, J. A., Norman, V. L., O’Neil-Johnson, M., Eldridge, G. R., et al. (2017). Isolation and identification of the novel tubulin polymerization inhibitor bifidenon. J. Nat. Prod. 80, 616-624. doi: 10.1021/ acs.jnatprod.6b00893

Wright, A. D., Schupp, P. J., Schrör, J.-P., Engemann, A., Rohde, S., Kelman, D., et al. (2012). Twilight zone sponges from Guam yield theonellin isocyanate and psammaplysins I and J. J. Nat. Prod. 75, 502-506. doi: 10.1021/np200939d
Zhang, B., Zhang, T., Xu, J., Lu, J., Qiu, P., Wang, T., et al. (2020). Marine sponge-associated fungi as potential novel bioactive natural product sources for drug discovery: a review. Mini Rev. Med. Chem. 20, 1966-2010. doi: 1 $0.2174 / 1389557520666200826123248$

Zhao, J., Feng, J., Tan, Z., Liu, J., Zhao, J., Chen, R., et al. (2017). Stachybotrysins A-G, phenylspirodrimane derivatives from the fungus Stachybotrys chartarum. J. Nat. Prod. 80, 1819-1826. doi: 10.1021/acs.jnatprod.7b00014

Zheng, H., Zhang, Z., Liu, D. Z., and Yu, Z. F. (2019). Memnoniella sinensis sp. nov., a new species from China and a key to species of the genus. Int. J. Syst. Evol. Microbiol. 69, 3161-3169. doi: 10.1099/ijsem.0. 003605

Conflict of Interest: The authors declare that the research was conducted in the absence of any commercial or financial relationships that could be construed as a potential conflict of interest.

Copyright (c) 2021 Wang, Zhou, Zou, Shi, Zhou, Shao, Yu, Cui, Li, Wu, Ye, Yan, Naman, Lazaro and He. This is an open-access article distributed under the terms of the Creative Commons Attribution License (CC BY). The use, distribution or reproduction in other forums is permitted, provided the original author(s) and the copyright owner(s) are credited and that the original publication in this journal is cited, in accordance with accepted academic practice. No use, distribution or reproduction is permitted which does not comply with these terms. 